\title{
REVENGE PORN A DEEPFAKES: OCHRANA SOUKROMÍ V ÉŘE MODERNÍCH TECHNOLOGIÍ
}

\author{
MICHAELA DVOŘÁKOVÁ
}

\begin{abstract}
ABSTRAKT
Rozvoj moderních technologií je neodlučitelně spojen $s$ novými způsoby zásahů do práva na soukromí. $V$ uplynulých letech se mnoho lidí osobně setkalo $s$ jedním z nich, fenoménem přezdívaným revenge porn (anebo obecněji nekonsenzuální pornografie). Po internetu byly totiž šíreny jejich intimní anebo sexuální fotografie či videa, která bud'to někdo nedovoleně rozššřil, anebo dokonce $i$ poř́dil bez jejich vědomí. Od roku 2017 je hrozba $v$ tomto směru ještě o poznání větší, a to z důvodu rozvoje technologie deepfake, která umožňuje takové záznamy dokonce uměle vytvářet. A přestože představuje i jiná rizika, prozatím se rozšǐřila prevážně $v$ oblasti nedovoleně vytvářených sexuálních záznamů. Téměr̆ kdokoliv tak na internetu může $v$ budoucnu najít pornografické video, $v$ němž účinkuje, aniž by jej kdy natočil. Taková skutečnost pochopitelně zakládá znatelný zásah do práva na soukromí. Otázkami ohledně rozvoje pornografických deepfakes a souvisejícími právními aspekty se tento článek zabývá.
\end{abstract}

\section{KLÍČOVÁ SLOVA}

nekonsenzuální pornografie, revenge porn, technologie deepfake, pornografická deepfake videa, ochrana soukromí, nekontaktní sexuální násilí, image-based sexual abuse (IBSA)

\footnotetext{
1 Mgr. Bc. Michaela Dvořáková je doktorandkou na Katedře ústavního práva a politologie Právnické fakulty Masarykovy univerzity a asistentkou soudce Nejvyššího správního soudu, e-mail: 407928@mail.muni.cz.
} 


\begin{abstract}
The development of modern technologies is inextricably linked to new means of privacy rights invasions. In recent years, many people have personally experienced one of them, the phenomenon of revenge porn (or more generally non-consensual pornography). Their intimate and/or sexual photographs or video records, which were either shared without their permission, or even taken without their knowledge, were distributed on the Internet. Since 2017, the threat has become even greater, due to the development of deepfake technology allowing to artificially create such recordings. Although it poses risks in different areas as well, it has so far predominantly spread in the area of illicitly created sexual recordings. In the future, almost anyone can find a pornographic video starring himself on the Internet, without him ever making one. Such eventuality naturally constitutes a significant interference with the right to privacy. This article addresses issues regarding the development of pornographic deepfakes and related legal aspects.
\end{abstract}

\title{
KEYWORDS
}

non-consensual pornography, revenge porn, deepfake technology, deepfake pornography videos, privacy protection, non-contact sexual violence, imagebased sexual abuse (IBSA)

\section{1. ÚVOD}

V roce 2014 na internet uniklo ohromné množství intimních fotografií stovek slavných žen, které hackeři stáhli z online úložište, do nichž se nabourali. $^{2}$ Tato vysoce medializovaná aféra (přezdívaná „celebgate“ anebo „nudegate“) se stala ukázkou toho, v čem spočívá a jaký účinek má tzv. revenge porn, tedy nedovolené šíření sexuálních fotografií či videozáznamů určité osoby. V roce 2019 už bylo možno na internetu zhlédnout slavné he-

2 LENHART, Amanda; YBARRA, Michelle; PRICE-FEENEY, Myeshia. Nonconsensual Image Sharing: one in 25 Americans has been a victim of "Revenge Porn". In: Data \& Society Research Institute [online]. 13. 12. 2016 [cit. 28. 4. 2020], s. 3. Dostupné z: https://datasociety.net/pubs/oh/Nonconsensual_Image_Sharing_2016.pdf 
rečky (např. Emmu Watson, Scarlett Johansson, ${ }^{3}$ Gal Gadot, Masie Williams, Daisy Ridley a mnoho dalších $\left.{ }^{4}\right)$ v pornografických videích. A to, aniž by jakákoliv taková videa někdy natočily. Objevil se totiž nový inteligentní algoritmus, který umožnil rozvoj tzv. deepfakes - vysoce realistických, avšak uměle vytvořených videí. A tato technologie se rozšíríla právě $\mathrm{v}$ oblasti pornografie.

Co mají oba pojmy, tedy revenge porn a pornografická deepfakes společného? Zaprvé, z převážné většiny jsou jejich obětmi ženy. ${ }^{5}$ Zadruhé, jejich podstata je velmi obdobná. Zjednodušeně řečeno spočívají $\mathrm{v}$ nedovoleném vytváření anebo šîrení sexuálních záznamů vyobrazujících osobu, která $\mathrm{k}$ jejich vytváření anebo šíření nedala souhlas. Tímto způsobem samozřejmě dochází zejména $\mathrm{k}$ podstatnému zásahu do soukromí jednotlivce, který je mnohonásobně zesílen užíváním moderních technologií. ${ }^{6}$ Dopady, které takové jednání může mít na životy obětí, jsou přitom podle odborníků srovnatelné s dopady sexuálního zneužívání. ${ }^{7}$ Přestože popsaný zásah do soukromí míři do oblasti lidské sexuality a intimní individuality, kterou Evropský soud pro lidská práva (dále "ESLP") nazývá „nejintimnějš́ sférou jednotlivce“ ${ }^{8}$ neexistuje proti němu účinná, efektivní a rychlá ochrana. Internet totiž nezapomíná. ${ }^{9}$ Oběti revenge porn a pornografických deepfakes tak jsou ponechány v boji s větrnými mlýny. Z popisu jejich zkušeností vy-

3 SPIVAK, Russell. "Deepfakes": The Newest Way to Commit One of the Oldest Crimes. Georgetown Law Technology Review [online]. 2019, roč. 3,č. 2 [cit. 27. 4. 2020], s. 345-346. Dostupné z: https://georgetownlawtechreview.org/wp-content/uploads/2019/05/3.1-Spiv ak-pp-339-400.pdf

4 Tamtéž, s. 339.

5 DELFINO, Rebecca. Pornographic Deepfakes: The Case for Federal Criminalization of Revenge Porn's Next Tragic Act. Fordham Law Review [online]. 2019, roč. 88, 3 [cit. 27. 4. 2020], s. 896. Dostupné z: https://ir.lawnet.fordham.edu/flr/vol88/iss3/2/

6 Srov. MCGLYNN, Clare; RACKLEY, Erika. Image-Based Sexual Abuse. Oxford Journal of Legal Studies [online]. 2017, roč. 37, 3 [cit. 27. 4. 2020], s. 560-561. Dostupné z: https:// academic.oup.com/ojls/article-abstract/37/3/534/2965256?redirectedFrom = fulltext

7 BATES, Samantha. Revenge Porn and Mental Health: A Qualitative Analysis of the Mental Health Effects of Revenge Porn on Female Survivors. Feminist Criminology [online]. 2017, roč. 12, 1 [cit. 27. 4. 2020], s. 31. Dostupné z: http://journals.sagepub.com/doi/abs/10. $1177 / 1557085116654565$

8 Rozsudek Evropského soudu pro lidská práva ze dne 22. 10. 1981. Dudgeon vs. Spojené království. ECHR 7525/76. In: HUDOC [online]. Evropský soud pro lidská práva [cit. 29. 4. 2020], bod 52. Dostupné z: http://hudoc.echr.coe.int/eng?i=001-57473 
plývá, až ačkoliv se jim třeba podařilo dosáhnout odstranění jejich nedovoleně šířeného sexuálního záznamu z webových stránek, ${ }^{10}$ na nichž byl uveřejněn, nadále žily $\mathrm{v}$ nekonečné obavě $\mathrm{z}$ toho, kdy a kde se tento materiál zase vynoři. ${ }^{11} \mathrm{~V}$ tomto směru dle svých slov zažívaly pocit ztráty kontroly nad tím, kdo vše záznam uvidí. ${ }^{12}$ Mimo jiné i proto se tak mnozí z těch, kteří tento moderní fenomén zažili na vlastní kůži, museli např. stáhnout z veřejného života anebo online prostředí, změnit práci, přestěhovat ${ }^{13}$ se či se potýkali s vážnými mentálními problémy. ${ }^{14}$ A někteří $\mathrm{z}$ nich dokonce spáchali sebevraždu. ${ }^{15}$

Tento článek nejprve popíše, jaké typy jednání lze za nekonsenzuální pornografii označit, $\mathrm{v}$ čem spočívají a jakým způsobem $\mathrm{k}$ nim může docházet. Poté se bude podrobněji věnovat tématu deepfake pornografie, která se zkoumanou problematikou úzce souvisí. Jelikož se v českém právním prostředí jedná o první text, který se pornografickým deepfake videím věnuje, pokusí se autorka stručně nastínit i formy zásahu do individuálních práv na straně oběti a prostředky, jimiž se proti tomu lze bránit.

\section{REVENGE PORN A NEKONSENZUÁLNÍ PORNOGRAFIE}

Hned na začátku tohoto článku je nutno vysvětlit užívanou terminologii. ${ }^{16}$ Přestože termín revenge porn (česky „pornopomsta“) je mezi laickou veřejností extenzivně užíván pro popis všech případů nedovoleného šíření se-

9 ROSEN, Jeffrey. The Web Means the End of Forgetting. In: The New York Times Magazine [online]. 21. 7. 2010 [cit. 27. 4. 2020]. Dostupné z: https://www.nytimes.com/2010/07/ 25/magazine/25privacy-t2.html

10 Zejména v zahraničí vznikly dokonce specializované webové stránky sloužící pro zveřejňování a sdílení revenge porn, tzv. „revenge porn sites“. Srov. WINKLEY, Lyndsay; LITTLEFIELD, Dana. Sentence revised for revenge porn site operator. In: The San Diego UnionTribune [online]. 21. 9. 2015 [cit. 27. 4. 2020]. Dostupné z: http://www.sandiegouniontribune.com/sdut-kevin-bollaert-revenge-porn-case-resentencing-2015sep21-story.html

11 BATES, op. cit., s. 31.

12 Tamtéž, s. 33-34.

13 MCGLYNN, RACKLEY, op. cit., s. 545.

14 BATES, op. cit., s. 31-33.

15 MCGLYNN, RACKLEY, op. cit., s. 545.

16 S ohledem na poněkud krkolomné překlady některých pojmů užívá autorka tohoto textu převážně anglickou terminologii. 
xuálních záznamů (a v tomto směru představuje určitou mediální zkratku, užitou i v názvu tohoto článku), je vhodnější hovořit bud’to o tzv. nekonsenzuální pornografii, ${ }^{17}$ anebo tzv. „image-based sexual abuse” („IBSA“, v překladu „sexuální zneuživání založené na obrazovém znázornění“). ${ }^{18}$ Poslední uvedený termín nejvíce vystihuje podstatu problému a zároveň zastřešuje naprostou většinu případů nedovoleného vytváření anebo šíření sexuálních záznamů jiné osoby. ${ }^{19}$ Pojem revenge porn totiž naznačuje, že k jednání dochází za účelem pomsty („revenge“), což může být poněkud zavádějící. Přestože tomu tak mnohdy může být (jak bude rozebráno níže), není to podmínkou ve všech případech, a podle některých autorů není žádoucí užívat pojmosloví zaměřené na úmysl pachatele, a nikoliv na újmu na straně oběti. ${ }^{20}$ Není však účelem tohoto článku rozhodnout, který z užívaných pojmů je pro označování zkoumané problematiky vhodnější. Pojmy nekonsenzuální pornografie, revenge porn (largo sensu, nikoliv pouze za účelem pomsty) a IBSA bude autorka používat jako vzájemná synonyma, a to vzhledem k tomu, že se všechny užívají v zahraničních odborných textech, které se tomuto tématu věnují. ${ }^{21} \mathrm{~K}$ nim přidává ještě další, poněkud deskriptivní pojem „nedovolené šîření sexuálních záznamů“.

V čem zkoumaná problematika vlastně spočívá? Nekonsenzuální pornografií je v principu šîrení snímků se sexuálním vyobrazením jedince bez jeho souhlasu. ${ }^{22}$ Takové jednání můžeme obecně charakterizovat jako jednu z forem nekontaktního sexuálního násilil, ${ }^{23}$ která může mít závažné dopady nejen do práv jednotlivce, ale i do jeho postavení v rámci společnosti, dů-

17 CITRON, Danielle Keats; FRANKS, Mary Anne. Criminalizing Revenge Porn. Wake Forest Law Review [online]. 2014, roč. 49, [cit. 27. 4. 2020], s. 346. Dostupné z: http://reposit ory.law.miami.edu/cgi/viewcontent.cgi?article $=1059 \&$ context $=$ fac_articles

18 MCGLYNN, RACKLEY, op. cit., s. 535-544.

19 Tamtéž, s. 536-537.

20 Tamtéž.

${ }^{21}$ Terminologickou problematiku zkoumaného tématu blíže vysvětlují HENRY, Nicola; FLYNN, Asher; POWELL, Anastasia. Responding to 'revenge pornography': Prevalence, nature and impacts [online]. Canberra: Australian Research Council, 2019 [cit. 27. 4. 2020], s. 12-14. Dostupné z: https://www.crg.aic.gov.au/reports/CRG_08_15-16-FinalReport.pdf

22 FRANKS, Mary Anne. Combating Non-Consensual Pornography: A Working Paper. In: SSRN [online]. 7. 9. 2014 [cit. 27. 4. 2020], s. 3. Dostupné z: https://papers.ssrn.com /sol3/papers.cfm?abstract_id $=2336537$ 
stojnosti a pocitu vlastní hodnoty. Tento zásah je obzvlášt citlivý, nebot’ se dotýká lidské sexuality, touhy po vlastním sebeurčení a mnohdy i ohrožení na pocitu osobního bezpečí, a to dokonce i v reálném, fyzickém světě. Skutečnost, že se po internetu mohou šířit vaše intimní anebo sexuálně explicitní snímky a videa (at̉ už skutečná, nebo uměle vytvořená) se tedy zásadně liší např. od neoprávněného nakládání s osobními údaji či od pomluvy, ${ }^{24}$ a to kvůli tomu, že podstata tohoto jednání leží právě v oné sexuální oblasti. Jednoduše řečeno, pokud by obsah nekonsenzuální pornografie nezobrazoval něco, co je běžně cizím očím skryto a co je považováno ryze za soukromé, nebyl by tento typ jednání natolik populární a nezpůsoboval by tak závažnou újmu na straně obětí.

Z amerického výzkumu z roku 2017 vyplynulo, že $8 \%$ všech dotázaných v minulosti čelilo nedovolenému šíření svých intimních či sexuálních záznamů a dalším $5 \%$ dotázaných bylo takovým jednáním alespoň vyhrožováno. ${ }^{25}$ Zároveň se ukázalo, že se obětmi tohoto jednání stávají výrazně častěji ženy ${ }^{26,27}$ anebo příslušníci LGBT komunity. ${ }^{28}$ Mnohdy navíc nezůstane „jen“ u samotného šíření takového typu záznamu, často musí oběti čelit dalším souvisejícím projevům, kterými může být ponižování, šikana, nedovolené pronásledování, vyhrožování či vydírání. Oběti uveřejnění nekonsenzuální pornografie jsou mnohdy navíc vystaveny množství verbálního násilí, které má nejen dehonestující charakter, ale může ob-

23 POWELL, Anastasia; HENRY, Nicola. Sexual Violence in a Digital Age [online]. Basingstoke: Palgrave Macmillan, 2017 [cit. 27. 4. 2020], s. 61. Dostupné z: https://link.springer.com /book/10.1057\%2F978-1-137-58047-4

${ }^{24}$ V tomto kontextu je nutno vysvětlit, že právě tyto skutkové podstaty spadají do Hlavy II dílu 2 zákona č. 40/2009 Sb., trestního zákoníku, která mj. zajištuje ochranu osobnosti, soukromí a listovního tajemství.

25 EATON, Asia A.; JACOBS, Holly; RUVALCABA, Yanet. 2017 Nationwide Online Study of Nonconsensual Porn Victimization and Perpetration. A Summary Report. In: Cyber Civil Rights Initiative [online]. (C)2017 [cit. 27. 4. 2020], s. 11. Dostupné z: https://www.cybercivilrights.org/wp-content/uploads/2017/06/CCRI-2017-Research-Report.pdf

26 EATON, JACOBS a RUVALCABA, op. cit., s. 12, anebo MCGLYNN, RACKLEY, op. cit., s. 544.

27 Někteří autoři však upozorňují, že se obětmi uveřejnění nekonsenzuální pornografie stávají obdobně často i muži. $\mathrm{V}$ jejich případě ale dochází výrazně méně častěji k vyhrožování $\mathrm{z}$ uveřejnění těchto záznamů. Viz LENHART, YBARRA a PRICE-FEENEY, op. cit., s. 5.

28 Tamtéž. 
sahovat i výhružky znásilněním. ${ }^{29} \mathrm{Ti}$, kteří se stanou obětmi tohoto jednání, tak zažívají skutečný strach, někteří se obávají vycházet $\mathrm{z}$ domu ${ }^{30}$ a často musí měnit své životy a zažité zvyky. Bývalá americká kongresmanka Katie Hill rezignovala na svůj mandát poté, co bulvární a pravicová média zveřejnila intimní fotografie, na nichž je zobrazena se svou bývalou podřízenou. $V$ poslední řeči na půdě Sněmovny reprezentantů uvedla, že úřad opouští kvůli „tisícům odporných, vyhrožujících e-mailů, hovorů a zpráv," které v ní vyvolaly „strach o vlastní život a život jejích blízkých.“ Dodala, že je vyděšená, nebở poprvé od uveřejnění uvedených snímků opustila svůj byt. $^{31}$

Oběti IBSA se také musí často vypořádat s posttraumatickým syndromem, úzkostí, depresemi a sebevražednými tendencemi, nikoliv nepodobnými stavům, které zažívají oběti fyzických sexuálních útoků. ${ }^{32}$ Jak bylo navíc zmíněno $\mathrm{v}$ úvodu, některé příběhy obětí nekonsenzuální pornografie dokonce končí předčasnou smrtí. Např́klad Italka Tiziana Cantone spáchala v roce 2016 sebevraždu poté, co se stala předmětem širokého virálního posměchu kvưli obsahu uniklého soukromého videa, na kterém provozuje sexuální aktivity a které se stalo internetovou senzací. ${ }^{33}$ Lze zmínit i dva př́pady z roku 2013. Sedmnáctiletá Brazilka Julia Rebecca se oběsila po úniku své sexuální nahrávky ${ }^{34}$ a stejně starý Daniel Perry ze Skotska skočil z mostu pod tlakem vydírání uveřejnění jeho explicitní nahrávky, kterou útočníci lstí pořídili přes online aplikaci Skype..$^{35}$

29 CITRON, FRANKS, op. cit., s. 353.

30 Tamtéž, s. 351.

31 GESSEN, Masha. The Terrorization of Katie Hill. In: The New Yorker [online]. 5. 11. 2019 [cit. 27. 4. 2020]. Dostupné z: https://www.newyorker.com/news/our-columnists/the-terr orization-of-katie-hill

32 BATES, op. cit., s. 31-33.

33 REYNOLDS, James. Italy's Tiziana: Tragedy of a woman destroyed by viral sex video. In: $B B C$ [online]. 13. 2. 2017 [cit. 27. 4. 2020]. Dostupné z: http://www.bbc.com/news/ world-europe-38848528

34 BERGER, Miriam. Brazilian 17-Year-Old Commits Suicide After Revenge Porn Posted Online. In: BuzzFeed News [online]. 20.11. 2013 [cit. 27. 4. 2020]. Dostupné z: https:// www.buzzfeed.com/miriamberger/brazilian-17-year-old-commits-suicide-after-revengeporn-pos?utm_term =.1xoO1z9r4\#.txZ2n7aGr 
Z popsaných případů se může zdát, že se tento fenomén České republice vyhýbá. Bohužel tomu tak není, přestože se mu zde nedostává takové pozornosti jako v zahraničí. V roce 2013 vzniklo na sociální síti Facebook několik stránek, jejichž účelem bylo sdílet uživateli zaslané fotografie tzv. „roztahovaček“ (údajně promiskuitních dívek z okolí). Tyto stránky byly vždy zaměřeny na určitou lokalitu, zejména konkrétní město (např. „brněnské roztahovačky“) a na nich uveřejněné fotografie zobrazovaly dívky (často středoškolačky, některé mladší 15 let) nahé, obnažené či v jiných vyzývavých pózách. Tyto fotografie doprovázely $\mathrm{i}$ hanlivé komentáře $\mathrm{k}$ vyobrazeným dívkám, případně přímé odkazy na jejich facebookové profily. ${ }^{36}$ Facebook tyto stránky následně na základě oznámení zrušil, nicméně bulvární média v mezičase stihla o celé záležitosti na svých portálech informovat jako o senzaci, přičemž články doplnila těmito nedovoleně uveřejněnými fotografiemi. Po zrušení facebookých stránek některá $\mathrm{z}$ těchto médií dokonce dále čtenáře odkázala na nově vzniklé internetové stránky, kam byly fotografie přesunuty. ${ }^{37}$ Policie také v posledních letech opakovaně upozorňuje na riziko zneužití intimních fotografií zaslaných v soukromé konverzaci anebo jinak zpřístupněných, které mohou být šiřreny anebo mohou vést $\mathrm{k}$ vydírání oběti vyhrožováním jejich zveřejněním. Z webových stránek Policie ČR je patrné, že i u nás $\mathrm{k}$ jednání spadajícímu pod nekonsenzuální pornografii dochází poměrně často. ${ }^{38} \mathrm{Je}$ likož však může nabývat různých podob a jejich vzájemná souvislost nemu-

35 SMITH-SPARK, Laura; VANDOORNE, Saskya. Reports: Teen Daniel Perry commits suicide over Skype blackmail scam. In: $C N N$ [online]. 16. 8. 2013 [cit. 27. 4. 2020]. Dostupné z: https://edition.cnn.com/2013/08/16/world/europe/uk-cyber-blackmail-suicide/ index.html

36 ŽLÁBKOVÁ, Ludmila. Snímky polonahých dívek od zhrzených partnerů zaplavily český internet. In: Novinky.cz [online]. 9.11. 2014 [cit. 27. 4. 2020]. Dostupné z: https:// www.novinky.cz/internet-a-pc/352987-snimky-polonahych-divek-od-zhrzenych-partneruzaplavily-cesky-internet.html

${ }^{37}$ Např́íklad server pořadu Prásk televize Nova.cz s článkem nazvaným „Kam zmizely všechny roztahovačky?", který je dnes již nedostupný. Srov. DVOŘÁKOVÁ, Michaela. Právo na informační sebeurčení a nedovolené šǐrení sexuálních záznamů [online]. Brno, 2018 [cit. 29. 4. 2020]. Diplomová práce. Masarykova univerzita, Právnická fakulta. Vedoucí práce Kateřina ŠIMÁČKOVÁ, s. 20. Dostupné z: https://is.muni.cz/th/t361z/ 
sí být zřejmá, následující podkapitola vymezí, jaké všechny druhy jednání pod nekonsenzuální pornografii neboli tzv. „image-based sexual abuse“ patří.

\subsection{TYPOLOGIE „IMAGE-BASED SEXUAL ABUSE“}

Jednání naplňující podstatu IBSA ${ }^{39}$ může mít typově tři různé formy: 1) vytváření sexuálních záznamů bez souhlasu vyobrazené osoby, 2) zveřejnění, šírení anebo sdílení sexuálních záznamů bez souhlasu vyobrazené osoby, 3) vyhrožování zveřejněním, šířením anebo sdílením sexuálních záznamů jiné osoby. ${ }^{40} \mathrm{~V}$ praxi nebývají mnohdy tyto druhy odděleny, naopak dochází $\mathrm{k}$ jejich vzájemné kombinaci a zároveň k prolínání s dalšími níže popsanými kategoriemi. K tomu je ještě nutno dodat, že ačkoliv k těmto druhům jednání může docházet i bez užití moderních technologií, ${ }^{41}$ jejich všudypřítomná dostupnost je značně usnadňuje a urychluje. ${ }^{42}$

IBSA lze dále rozlišovat ${ }^{43} \mathrm{z}$ hlediska okolností, za nichž $\mathrm{k}$ předmětnému jednání dochází. První skupinu tak tvoří jednání spočívající v určité „vztahové odplatě“، ${ }^{44} \mathrm{v}$ tomto případě se tedy jedná o revenge porn stricto sensu. Typickým př́kladem je, že osoba v průběhu vztahu zašle partnerovi své intimní fotografie, který je po následném rozchodu rozešle jiným lidem

38 Srov. Např.: JANDA, Petr. Zneužití fotografie. In: Policie České republiky - KŘP Královéhradeckého kraje [online]. 7. 3. 2012 [cit. 29. 4. 2020]. Dostupné z: https://www.policie.cz/ clanek/zneuzite-fotografie.aspx; MATZNER, Jiří. Vydírá expřítelkyni zveřejněním intimních fotografií. In: Policie České republiky - Ǩ̌P Jihočeského kraje [online]. 3. 5. 2015 [cit. 29. 4. 2020]. Dostupné z: http://www.policie.cz/clanek/vydira-expritelkyni-zverejnenim-intimnich-fotografii.aspx; BURÝŠKOVÁ, Lenka. Vydíral ženu přes facebook. In: Policie České republiky - KŘP Královéhradeckého kraje [online]. 2. 9. 2016 [cit. 29. 4. 2020]. Dostupné z: http://www.policie.cz/clanek/vydiral-zenu-pres-facebook.aspx; KYŠNEROVÁ, Simona. Vydíral ji jejími nahými fotkami. In: Policie České republiky - KŘP Zlínského kraje [online]. 12. 1. 2017 [cit. 29. 4. 2020]. Dostupné z: http://www.policie.cz/clanek/vydiralji-jejimi-nahymi-fotkami.aspx; ZÁMEČNÍK, Petr. Začalo to nevinně. In: Policie České republiky - KŘP Jihomoravského kraje [online]. 23. 3. 2018 [cit. 29. 4. 2020]. Dostupné z: https://www.policie.cz/clanek/zacalo-to-nevinne.aspx; DRAHOKOUPILOVÁ, Lenka. Prozrazení hesla se jí nevyplatilo. In: Policie České republiky - Ǩ̌P Jihomoravského kraje [online]. 12.12. 2019 [cit. 29. 4. 2020]. Dostupné z: https://www.policie.cz/clanek/prozrazeni-hesla-se-ji-nevyplatilo.aspx

39 Autorka typologie, z níž tento článek vychází, používá pro nedovolené šíření sexuálních záznamů pojem IBSA, proto se v této podkapitole jedná o převažující termín popisující zkoumané jednání. Jak však bylo vysvětleno výše, jedná se významově o synonymum k pojmům nekonsenzuální pornografie anebo revenge porn. Viz POWELL, HENRY, op. cit., s. 120-132.

40 Tamtéž, s. 120. 
(např. přátelům, rodině či zaměstnavateli vyobrazené osoby), anebo je zveřejní na sociální sítě či jiné internetové stránky. ${ }^{45}$ Samozřejmě se však může jednat i o jiné situace, významným faktorem však je vzájemný vztah mezi tím, kdo se IBSA v tomto př́padě dopouští, a jeho obětí. ${ }^{46} \mathrm{~V}$ tomto př́ípadě tak lze předpokládat jako hlavní motiv snahu oběti co nejvíce ublížit. Proto nezřídka dochází i ke zveřejnění jejích osobních anebo kontaktních údajů (případně odkazů na profil na sociální síti), ${ }^{47}$ či dokonce falešných „pornoinzerátư“" nabízejících sexuální služby. ${ }^{48}$ To umožňuje, aby jiné osoby obět IBSA kontaktovaly, př́ípadně se vůči nim dopouštěly nedovoleného pronásledování (tzv. stalkingu). ${ }^{49}$

${ }^{41}$ Již v 80. letech 20. stol. zavedl např́íklad americký magazín Hustler's rubriku nazvanou „Beaver Hunt“, do které čtenáři přispívali fotografiemi nahých žen ze svého okolí. Viz LEWENDOWSKI, Amanda. Our Best Weapon Against Revenge Porn: Copyright Law?. In: The Atlantic [online]. 4. 2. 2014 [cit. 29. 4. 2020]. Dostupné z: https://www.theatlantic.com/technology/archive/2014/02/our-best-weapon-against-revenge-porn-copyright-law/ 283564/

${ }^{42}$ POWELL, HENRY, op. cit., s. 120.

${ }^{43} \mathrm{~V}$ úvahu připadají i další různá dělení, např. z hlediska formy šiření záznamu (např. soukromou zprávou, zveřejněním na veřejné internetové stránce, zveřejněním na osobním profilu na sociální síti), nebo třeba z hlediska toho, nakolik "nahá“ a sexuálně explicitně vyobrazená osoba na záznamu je, př́padně při jaké činnosti (např. ve sprše anebo při sexuálním aktu). Srov.: HENRY, FLYNN, POWELL, op. cit., s. 14.

44 Tamtéž.

${ }^{45}$ POWELL, HENRY, op. cit., s. 121.

${ }^{46}$ Srov. BATES, op. cit., s. 29.

47 Podle amerického výzkumu z roku 2013 bylo v $60 \%$ případů revenge porn zveřejněno celé jméno vyobrazené osoby, v $50 \%$ právě odkaz na profil na sociálních sítích. Ve $20 \%$ případů bylo zveřejněno telefonní číslo oběti, v $15 \%$ pak adresa jejího bydliště či pracoviště. Srov. 2013 NCP Study Results. In: Cyber Civil Rights Initiative [online]. (C2018 [cit. 27. 4. 2020]. Dostupné z: https://www.cybercivilrights.org/wp-content/ uploads/2016/11/NCP-2013-Study-Research-Results-1.pdf

${ }^{48}$ Na tomto místě je samozrejmě nutno připomenou kauzu bývalého fotbalisty Tomáše Řepky, který společně se svou současnou př́itelkyní vytvořil na internetu falešný inzerát nabízející sexuální služby pod jménem své bývalé manželky. Za to a další trestnou činnost byl v roce 2019 odsouzen k nepodmíněnému trestu odnětí svobody. Více viz: Tomáš Řepka půjde do vězení, odvolací soud mu zvýšil trest. In: iROZHLAS [online]. 30. 4. 2019 [cit. 30. 4. 2020]. Dostupné z: https://www.irozhlas.cz/sport/fotbal/tomas-repka-vezeni-odvolaci-soud-2roky-sparta-praha-zpronevera_1904301028_vman

49 Jedna z žen, která se stala obětí IBSA, popsala, že za ní domů chodili cizí muži žádající o sexuální aktivity. Jeden z nich se $\mathrm{k}$ ní vloupal a škrtil ji. Její bývalý přítel těmto mužům totiž rozesílal její nahé fotografie a adresu bydliště společně s nabídkou sexu. Viz BATES, op. cit., s. 32. 
Dalším druhem IBSA je sexuální vydírání neboli „sextortion“. ${ }^{0}$ Jeho předmětem je vyhrožování zveřejněním anebo šířením sexuálních fotografií či videozáznamů, na nichž je daná osoba vyobrazena. Ta je tak nucena např. k zaslání dalšího (třeba i více „odvážného“) materiálu, k osobnímu setkání, anebo nezřídka i k fyzickým sexuálním aktivitám. ${ }^{51,52}$ Tuto formu IBSA (v podobě vydírání a následném zveřejnění zaslaných snímků) mohli diváci vidět $\mathrm{v}$ dokumentárním filmu $V$ síti tvůrců Víta Klusáka a Barbory Chalupové, který se zabývá sexuálními predátory vyhledávajícími na internetu nezletilé děti. Odborníci upozorňují, že právě v případě dětí představuje sexuální vydírání závažné riziko, nebot jsou snáze manipulovatelné a neumějí se proti takovému jednání samy bránit. ${ }^{53}$ Pro úplnost je nutno dodat, že tato forma IBSA spadá pod obecnou problematiku vydírání, ke které dochází i v jiných oblastech lidského života. I v tomto případě je však dopad takového vydírání specifický tím, že se dotýká velmi citlivé otázky lidské sexuality.

Mezi IBSA dále spadá tzv. sexuální voyeurismus (ve smyslu užívání moderních technologií, nikoliv pouhého pozorování jiných osob). Ten spočívá ve vytváření intimních, sexuálních, sexuálně explicitních anebo pornografických materiálů vyobrazujících osobu, která k jejich vytvoření neudělila souhlas. Projevuje se dále tím, že v jeho případě schází úmysl, aby se obět o tomto jednání dozvěděla. ${ }^{54}$ Takový záznam má sloužit spíše pro privátní účely (zejména sexuální gratifikaci), a to bud’to pro toho, kdo jej

50 POWELL, HENRY, op. cit., s. 120-132.

51 CITRON, Danielle Keats. Sexual Privacy. The Yale Law Journal [online]. 2018-2019, roč. 128, 7 [cit. 29. 4. 2020], s. 1924. Dostupné z: https://www.yalelawjournal.org/article /sexual-privacy

52 Viz např.: LADMANOVÁ, Dana. Důvěřivé ženy. In: Policie České republiky - KŘP Plzeňského kraje [online]. 27. 12. 2017 [cit. 29. 4. 2020]. Dostupné z: http://www.policie.cz/clanek/ duverive-zeny.aspx

53 Podle výzkumu Centra prevence rizikové virtuální komunikace Pedagogické fakulty Univerzity Palackého se pouze necelých 33 procent dětí svěří jiné osobě s tím, že někdo zneužil jejich intimní fotografie. Viz KOPECKÝ, Kamil; SZOTKOWSKI, René. Sexting a rizikové seznamování českých dětí v kyberprostoru. Výzkumná zpráva. In: Univerzita Palackého v Olomouci ve spolupráci se společností 02 Czech Republic [online]. (C2017 [cit. 29. 4. 2020]. Dostupné z: https://www.e-bezpeci.cz/index.php/ke-stazeni/vyzkumnezpravy/96-sexting-a-rizikove-seznamovani-2017/file

54 POWELL, HENRY, op. cit., s. 120-132. 
vytvořil, anebo i pro další osoby. Do této kategorie spadají záznamy ze skrytých kamer (např. v převlékárnách či převlékacích kabinkách, anebo pořízené skrytou kamerou při konsenzuální sexuální aktivitě), tajné sledování jiných osob skrze webkameru ${ }^{55}$ anebo získání nedovoleného přístupu k intimním anebo sexuálním záznamům jiné osoby (např. „nabouráním“ se do soukromého úložiště). Ve všech těchto případech je $\mathrm{z}$ povahy věci zřejmé, že k takto vytvořenému záznamu vyobrazená osoba neudělila souhlas, nebot? o něm zpravidla vůbec neví. ${ }^{56}$ U jejich vytváření je typické, že k nim dochází v situaci, kdy má obět bud’to očekávání soukromí a z něj plynoucího bezpečí ( $\mathrm{v}$ případě „nabourání“ počítačové webkamery ${ }^{57}$ anebo nafilmování konsenzuální sexuální aktivity bez vědomí jednoho ze zúčastněných), anebo sice na veřejném místě, avšak za očekávání určitého soukromí (napřr. skrytá kamera umístěná v převlékárně či převlékací kabince). $\mathrm{V}$ tomto bodě se však poněkud odlišuje další typ jednání spadající pod sexuální voyeurismus, kterým je tzv. „upskirting“ a tzv. „down-blousing““ ${ }^{58}$ V obou těchto prrípadech jde o pořizování fotografií či videozáznamů těla jiné osoby pod oblečením (pod sukní, resp. za výstřihem), a to většinou mobilním telefonem na veřejném místě, ${ }^{59}$ např. $v$ hromadných dopravních prostředcích anebo na eskalátorech. Tyto záznamy tedy sice vznikají na místě, na němž nelze příliš soukromí očekávat, avšak zpo̊sobem, který na-

${ }^{55} \mathrm{O}$ takovém případě u nás rozhodoval Nejvyšší soud. Jednalo se o to, že pronajímatel bytu umístil za zrcadlem v koupelně zařízení umožňující sledování nájemníků bez jejich vědomí a souhlasu za účelem vlastního sexuálního uspokojování. Srov. usnesení Nejvyššího soudu ze dne 14. 7. 2015, sp. zn. 4 Tdo 843/2015.

56 MCGLYNN, RACKLEY, op. cit., s. 543.

${ }^{57} \mathrm{~V}$ již zmiňovaném filmu $V$ síti popsala jedna z hereček, že když jí bylo 12 let, naboural se jí starší muž do webkamery. Přes tu ji bez jejího vědomí sledoval a potají nahrával, a to při převlékání či masturbaci. Později vyžadoval osobní schůzku a když dívka nepřišla, začal ji těmito záznamy vydírat. Viz HLAVÁČOVÁ, Veronika; DUCHKOVÁ, Anna. Internetový sexuální predátor se mi naboural do webkamery a sledoval, jak se převlékám, říká Monika. In: iROZHLAS [online]. 2. 3. 2020 [cit. 29. 4. 2020]. Dostupné z: https:// www.irozhlas.cz/zivotni-styl/spolecnost/internetovy-sexualni-predator-serial-pojd-si-semnou-psat-webkamera-v-siti_2003021909_jgr

58 CITRON, op. cit., s. 1914.

${ }^{59}$ KIRCHENGAST, Tyrone; CROFTS, Thomas. The legal and policy contexts of 'revenge porn' criminalisation: the need for multiple approaches. Oxford University Commonwealth Law Journal [online]. 2019, roč. 19, 1 [cit. 28. 4. 2020], s. 5. Dostupné z: https://www.tandfon line.com/doi/abs/10.1080/14729342.2019.1580518?journalCode $=$ rouc20 
rušuje hranice mezi tím, co je i ve veřejném prostoru soukromé, a tím, co je ve veřejném prostoru veřejné. Záznam nahého těla vyfoceného pod oblečením je v tomto směru porušením soukromí vyobrazené osoby i přesto, že vznikl na veřejném místě, nebot̉ i ve veřejném prostoru existuje sféra soukromí, ${ }^{60,}{ }^{61}$ která není určena očím veřejnosti, pokud se člověk nerozhodne ji veřejnosti odhalit. ${ }^{62,63}$

Další kategorií IBSA je tzv. „sexploitation“. Ta může kloubit výše uvedené případy, avšak takto získané sexuální záznamy zveřejňuje, šíří anebo sdílí za účelem zisku. ${ }^{64}$ Za tímto záměrem vznikly v zahraničí mnohé specializované internetové stránky. Například na serveru UGotPosted.com byly zveřejňovány sexuální záznamy vyobrazující osoby, které k tomu neudělily souhlas, a to společně s jejich osobními a kontaktními informacemi. Když následně tyto osoby žádaly o jejich smazání, server je odkazoval na stránku ChangeMyReputation.com, která po nich za stažení materiálu požadovala zaplatit stovky dolarů. ${ }^{65} \mathrm{~V}$ tomto kontextu je zároveň nutno podotknout, že $\mathrm{k}$ „sexploitation“ může docházet i na známých pornografických stránkách, nebot’ v kategorii amatérských videí je mnohdy velmi obtížné, anebo dokonce nemožné odlišit konsenzuálně natočená videa od těch nekonsenzuálních. ${ }^{66}$

Na závěr této typologie $\mathrm{z}$ hlediska okolností vzniku IBSA rozlišit ještě jeden, nejvíce znepokojující typ. Tím je záznam, distribuce anebo vy-

60 K tomu srov. NISSELBAUM, Helen. Protecting Privacy in an Information Age: The Problem of Privacy in Public. Law and Philosophy [online]. 1998, roč. 17, 5/6 [cit. 29. 4. 2020], s. 559-596. Dostupné z: https://www.jstor.org/stable/3505189?seq=1\#metadata_info _tab_contents

61 K tomu dále srov. rozsudek Evropského soudu pro lidská práva ze dne 28. 1. 2003. Peck vs. Spojené království. ECHR 44647/98. In: HUDOC [online]. Evropský soud pro lidská práva [cit. 29. 4. 2020], bod 62. Dostupné z: http://hudoc.echr.coe.int/eng?i = 001-60898

62 Danielle Citron zdůrazňuje, že takové jednání odnímá obětem „sexuální svobodu“, nebot’ podrývá jejich osobní rozhodnutí skrýt své genitálie a ňadra před zraky veřejnosti. V důsledku toho tak nemají kontrolu nad svou sexuální autonomií a konsentem. CITRON, op. cit., s. 1914.

63 K tomu dále srov. MCGLYNN, RACKLEY, op. cit., s. 542-543.

64 POWELL, HENRY, op. cit., s. 128.

65 Tamtéž, s. 128-129.

66 Tamtéž, s. 129. 
hrožování zveřejněním sexuálního napadení. Odborníci upozorňují, že taková forma IBSA je na vzestupu a stává se z ní určitý trend, byt doposud neexistují spolehlivá data, která by tyto závěry prokazovala. ${ }^{67}$ Již několik zahraničních medializovaných kauz znásilnění však bylo bud’to doprovázeno přímým „livestreamingem“ (živým vysíláním na sociálních sítích), ${ }^{68}$ anebo následným šířením fotografií anebo videozáznamu útoku na internetu. ${ }^{69} \mathrm{~V}$ těchto případech samozřejmě dochází k ohromnému zásahu do práv oběti již samotným sexuálním napadením. Tento zásah je však sekundárně doprovázen dalším ponížením, obtěžováním a viktimizací obětí, v důsledku čehož některé $\mathrm{z}$ těchto obětí čelí i vyhrožování smrtí. ${ }^{70}$ Zá- $^{-}$ roveň je i v tomto př́ípadě $\mathrm{z}$ povahy věci zřejmé, že obět k vytvoření takového záznamu nedala souhlas.

V kontextu revenge porn a nekonsenzuální pornografie často zaznívá námitka, že si za uveřejnění anebo šíření svých sexuálních snímků a videí mohou mnohé oběti samy, nebot jej neměly nikomu posílat, ${ }^{71}$ neměly jej vytvářet a měly dbát o to, aby nemohly být vytvořeny ani jiným způsobem. Na základě výše uvedeného je však zřejmé, že je naprosto lichá, právně irelevantní a spočívá $\mathrm{v}$ pouhé diskreditaci a sekundární viktimizaci těchto obětí (obecně je tzv. „victim blaming“ $u$ případů revenge porn poměrně obvyklý). Jednak jsou mnohé z těchto obětí nezletilé děti, ${ }^{72} \mathrm{v}$ jejichž případě je namístě vyšší míra ochrany jejich práv. A dále, což je pro tento článek

67 Tamtéž, s. 130.

68 Např.: ENGLAND, Charlotte. Teenager jailed for broadcast of girl's rape on online Periscope app. In: The Independent [online]. 15. 2. 2017 [cit. 28. 4. 2020]. Dostupné z: http://www. independent.co.uk/news/world/americas/teenager-marina-lonina-livestream-rape-17-yearold-friend-periscope-app-sentence-prison-columbus-a7581196.html

69 Viz např.: Steubenville Ohio School Footballers Guilty of Rape. In: $B B C$ [online]. 17. 3.2013 [cit. 29. 4. 2020]. Dostupné z: https://www.bbc.com/news/world-us-canada21823042; SANGHANI, Radhika. Chrissy Chambers: 'My rape became revenge porn in the UK'. In: The Telegraph [online]. 17. 6. 2015 [cit. 29. 4. 2020]. Dostupné z: https://www.telegraph.co.uk/women/womens-life/11677742/YouTube-Chrissy-Chambers-My-rape-becam e-revenge-porn-in-the-UK.html

70 MCGLYNN, RACKLEY, op. cit., s. 540.

71 Autorky Citron a Franks namítají, že by společnost neměla vinit oběti nekonsenzuální pornografie za to, že důvěřovaly blízké osobě a předaly jí intimní snímky, pokud zároveň chrání například oběti zneužití citlivých informací finančními poradci. CITRON, FRANKS, op. cit., s. 348 . 
podstatnější, ani sebeopatrnější osoba se nemůže zcela vyhnout tomu, aby se obětí nekonsenzuální pornografie rovněž stala. Mezi IBSA totiž přirozeně spadají i případy, kdy sexuální záznam nedovoleně vyobrazující konkrétní osobu není reálný, avšak jako reálný se jeví. Do této kategorie můžeme zařadit jak fotomontáže, tak zejména pornografická deepfakes - realistická, avšak uměle vytvořená videa. Těm se tento článek bude věnovat podrobněji.

\section{PORNOGRAFICKÁ DEEPFAKE VIDEA}

Problematika pornografických deepfakes se od doposud rozebíraných případů do určité míry liší, byt̉ se jedná o úzce související fenomén, jehož důsledky jsou ze své podstaty obdobné. Technologie deepfake vznikla v roce $2017^{73}$ a spočívá ve vytváření ultrarealistických nepravých videí ${ }^{74}$ osob, jejichž hlava je (velmi zjednodušeně řečeno) vložena namísto hlavy jiné osoby (tzv. "face swap"). ${ }^{75}$ Strojové učení přitom umožňuje nejen velmi uvěřitelné splynutí obrazu, ale zejména i převzetí pohybů, drobné mimiky a gest vyobrazené osoby. Stačí tedy skloubit cílové video - pro účely tohoto článku vybrané pornografické video - s množstvím snímků a videozáznamů (datasetem, tzv. "face setem“) osoby, kterou do tohoto videa chceme zakomponovat. ${ }^{76}$ Výsledkem tak je pornografická nahrávka, která na první

72 Srov. např.: MORAVČíK, Ondřej. Když čtrnáctiletá Kristýna... In: Policie České republiky Ǩ̌P Královéhradeckého kraje [online]. 20. 3. 2019 [cit. 29. 4. 2020]. Dostupné z: https:// www.policie.cz/clanek/kdyz-ctrnactileta-kristyna.aspx; KOZUMPLÍKOVÁ, Monika. Než pošleš nahou fotku, přemýšlej!. In: Policie České republiky - KǨP Zlínského kraje [online]. 31. 10. 2019 [cit. 29. 4. 2020]. Dostupné z: https://www.policie.cz/clanek/nez-poslesnahou-fotku-premyslej.aspx; SCHNEEWEISSOVÁ, Barbora. Sedmadvacetiletý muž několik let přes sociální sítě obtěžoval nezletilé dívky. In: Policie České republiky - KŘP Středočeského kraje [online]. 25.11. 2019 [cit. 29. 4. 2020]. Dostupné z: https://www.policie.cz/ clanek/sedmadvacetilety-muz-nekolik-let-pres-socialni-site-obtezoval-nezletile-divky.aspx; JIROUŠKOVÁ, Pavla. Láska přes internet nedopadla dobře. In: Policie České republiky - Ǩ̌P Moravskoslezského kraje [online]. 26.11. 2019 [cit. 29.4. 2020]. Dostupné z: https:// www.policie.cz/clanek/laska-pres-internet-nedopadla-dobre.aspx

73 DELFINO, op. cit., s. 893.

74 HARRIS, Douglas. Deepfakes: False Pornography Is Here and the Law Cannot Protect You. Duke Law \& Technology Review [online]. 2019, roč. 17, 1 [cit. 28. 4. 2020], s. 99. Dostupné z: https://scholarship.law.duke.edu/dltr/vol17/iss1/4/

75 Tamtéž. 
pohled vytváří dojem toho, že v ní účinkuje někdo, kdo ji však nikdy nenatočil.

Přestože má technologie deepfake širší uplatnění ${ }^{77}$ a představuje riziko ${ }^{78}$ i v jiných oblastech, ${ }^{79}$ podle odborných odhadů tvoří až $96 \%$ všech deepfake videí pornografická deepfakes. ${ }^{80}$ Stejně jako v ostatních případech IBSA se jejich obětmi stávají převážně ženy - v tomto případě dokonce ve $100 \%$ všech pornografických deepfakes. ${ }^{81}$ Internetovým uživatelům tak tato technologie umožňuje vytvářet pornografické nahrávky žen, které by si přáli vidět nahé. ${ }^{82}$ Většinou jsou jimi celebrity, ${ }^{83}$ a to $\mathrm{z}$ prostého důvodu - jejich "face set“ je snadno dostupný, nebot internet je plný jejich fotografií. ${ }^{84}$ Vznikají však samozřejmě i pornografická deepfakes s ženami, které slavné nejsou. Tvưrci těchto videí si vybírají převážně své známé, kamarádky, spolužačky či bývalé př́itelkyně. ${ }^{85,86} \mathrm{~K}$ usnadnění vytváření takových videí jim slouží jak aplikace, které dokáží automaticky shromáždit a propojit fotografie $\mathrm{z}$ profilu vytipované osoby na sociálních sítích, ${ }^{87}$ tak veřejně dostupné rady a návody. ${ }^{8}$ Doposud jsou sice mnohá takto vytvářená videa rozmazaná či nedokonalá z hlediska uvěřitelnosti, ${ }^{89}$ lze však předpokládat, že další rozvoj této technologie povede $\mathrm{k}$ jejich vylepšení. ${ }^{90}$

76 Technologie vytváření deepfakes se zakládá na pokročilém strojovém učení, v tomto případě hovoříme o tzv. „deep learning“. Více o tom, jak funguje, viz SPIVAK, op. cit.

77 Tato technologie nabízí i pozitivní možnosti užití, např. pro filmový průmysl.

78 Na rizika deepfakes poukázal např. americký komik Jordan Peele, který prostřednictvím této technologie vytvořil falešný projev bývalého prezidenta Baracka Obamy. Viz GSTALTER, Morgan. 'Obama' Voiced by Jordan Peele in PSA Video Warning About Fake Videos. In: The Hill [online]. 17. 4. 2018 [cit. 29. 4. 2020]. Dostupné z: https://thehill.com/blogs/ in-the-know/in-the-know/383525-obama-voiced-by-jordan-peele-in-psa-video-warningabout-fake

79 Riziku deepfake videí pro společnost a demokracii se obecně věnují např. CHESNEY, Robert; CITRON, Danielle Keats. Deep Fakes: A Looming Crisis for National Security, Democracy and Privacy? California Law Review [online]. 2019, roč. 107, 6 [cit. 29. 4. 2020 ]. Dostupné z: http://www.californialawreview.org/print/deep-fakes-a-looming-challengefor-privacy-democracy-and-national-security/

80 RAFFAGHELLO, Ida a kol. What Does a Feminist Approach to Deepfake Pornography Look Like?. In: Masters of Media [online]. 24. 10. 2019 [cit. 28. 4. 2020]. Dostupné z: https:// mastersofmedia.hum.uva.nl/blog/2019/10/24/what-does-a-feminist-approach-to-deepfakepornography-look-like/

81 RAFFAGHELLO, op. cit. 
Následující podkapitoly se budou věnovat otázce, jakou újmu pornografická deepfake videa vyobrazeným osobám způsobují. Na tomto místě je třeba pouze velmi krátce uvést, že obětí se nestává pouze osoba, jejíž podoba je ve videu užita (tedy osoba, které „patří hlava“), ${ }^{91}$ byt ta je samozřejmě postižena nejvíce - kdokoliv ji totiž může rozpoznat. Druhou obětí je ale i osoba, která byla zobrazena v původním videu (tedy osoba, které „patří tělo“), ${ }^{92}$ a která jej většinou natočila zcela konsenzuálně (a třeba i za úplatu). ${ }^{93}$ Pravděpodobně však aktérka původního videa neudělila souhlas k tomu, aby bylo zobrazováno pouze její nahé tělo, a namísto její hlavy byla vložena hlava jiné osoby. ${ }^{94} \mathrm{~V}$ tomto směru lze dle názoru autorky tohoto článku uvažovat o zásahu do lidské důstojnosti, nebot̉ se jedná do určité míry o objektivizaci. Upravené deepfake video může navíc zasahovat i do autorských práv k původnímu video, obzvlášt pokud se jednalo o profesionální pornografické video. Nicméně jakkoliv tato rovina rovněž otevírá zajímavé otázky, bude se tento text dále věnovat pouze zásahu do práv osoby, jejíž hlava je ve výsledném deepfake videu zobrazena.

${ }^{82}$ Jedna americká novinářka podotkla, že „deepfakes vznikla jako způsob, jak si přivlastnit ženská těla“. Viz COLE, Samantha. Deepfakes Were Created As a Way to Own Women's Bodies-We Can't Forget That. In: Vice [online]. 19. 4. 2018 [cit. 30. 4. 2020]. Dostupné z: https://www.vice.com/en_us/article/j5kk9d/deepfakes-were-created-as-a-way-to-ownwomens-bodieswe-cant-forget-that-v25n2

${ }^{83}$ DELFINO, op. cit., s. 894.

${ }^{84}$ Srov. HARRIS, op. cit., s. 100.

${ }^{85}$ Tamtéž, s. 101.

${ }^{86} \mathrm{~V}$ tomto směru se tak může jednat o IBSA ve formě „,vztahové odplaty“, nikoliv nepodobné revenge porn stricto sensu.

87 Po vzniku prvních pornografických deepfakes v roce 2017 se objevila online aplikace FakeApp, která jejich snadné vytváření sama umožňovala. DELFINO, op. cit., s. 893, anebo HARRIS, op. cit., s. 101.

${ }^{88}$ HARRIS, op. cit., s. 101.

89 DOLD, Kristen. Face-Swapping Porn: How a Creepy Internet Trend Could Threaten Democracy. In: Rolling Stone [online]. 17. 4. 2018 [cit. 29. 4. 2020]. Dostupné z: https:// www.rollingstone.com/culture/culture-features/face-swapping-porn-how-a-creepy-internettrend-could-threaten-democracy-629275/

${ }^{90}$ SIVAK, op. cit., s. 349.

91 DELFINO, op. cit., s. 898.

92 Tamtéž. 
Zkuste si nyní na okamžik představit, že se touto osobou stanete vy. Že někdo zneužije vaše fotky, které jste nahráli na své sociální sítě, a které vás vyobrazují v naprosto normálních životních situacích, a které nejsou ani intimní či lechtivé, natož pak sexuálně explicitní. Najednou se na internetu objeví pornografické video s vaší podobou, byt’ s jiným tělem. Po prvním zhlédnutí okamžitě víte, že je uměle vytvořené, že jste jej nikdy nenatočili. Ví to ale stejně dobře všichni vaši známí, kolegové anebo rodinní příslušníci, kteří jej také viděli anebo dokonce šířili? A i přesto, že je toto video falešné a nezobrazuje při sexuálních aktivitách vaše skutečné nahé tělo (ve skutečnosti zobrazuje neexistující osobu, nebot hlava a tělo k sobě nepatř́ ${ }^{95}$ ), necítili byste $\mathrm{v}$ takové situaci značný zásah do svých práv a do své osobnosti? Tento popis je samozřejmě velmi sugestivní, avšak ilustruje, v jaké pozici se oběti pornografických deepfakes ocitají. Z hlediska zkoumání zásahu do práv vyobrazené osoby je přitom nutno odlišit případný ${ }^{96}$ zásah spočívající v samotném vytvoření pornografického deepfake videa od zásahu, k němuž dojde jeho zveřejněním, sdílením či šířením. Ze své podstaty se totiž jedná o velmi rozdílné situace.

\subsection{VYTVOŘENÍ PORNOGRAFICKÉHO DEEPFAKE}

Zásah založený pouhým vytvořením pornografického deepfake je poněkud problematický. Z hlediska obecné roviny nekonsenzuální pornografie může k IBSA docházet samotným nedovoleným vytvořením intimního či sexuálního záznamu, a to způsoby, které tento text popisuje výše. V těchto ostatních případech však $\mathrm{k}$ vytvoření dochází bud'to narušením důvodně očekávaného soukromí (blíže viz podkapitola 2.1.), anebo zneužitím bezbrannosti oběti (typicky v případech záznamu sexuálního napadení). Při

\footnotetext{
93 Ačkoliv se tomu článek nebude dále věnovat, lze si představit i situaci, kdy deepfake video nebude založeno na „běžném“ komerčním pornografickém videu, ale např. na nahrávce znásilnění či jiných nekonsenzuálních sexuálních aktivit. Takové video, které by samo o sobě představovalo formu IBSA, pak může být dále zneužíváno ve vztahu $\mathrm{k}$ dalším osobám.

94 DELFINO, op. cit., s. 898.

95 DELFINO, op. cit., s. 897.

96 Lze si představit i situaci, kdy pornografické deepfake video vznikne se souhlasem vyobrazené osoby, aniž by jí nutně způsobovalo újmu na právech.
} 
vzniku pornografického deepfake videa nedochází ani k jedné z těchto situací. Tvưrce takového videa pro jeho vytvoření většinou používá fotografie vytipované oběti, které jsou běžně dostupné na internetu a sociálních sítích. $\mathrm{K}$ tomuto materiálu si tedy zpravidla nezjedná přistup způsobem, který by sám o sobě představoval zásah do soukromí na nich vyobrazené osoby, ani nijak nezneužije její bezbrannosti.

I přesto však může být samotné vytvoření pornografického deepfake videa zásahem do soukromí jednotlivce, konkrétněji do jeho práva na informační sebeurčení. Byt je toto právo [které je $\mathrm{v}$ našem právním řádu garantováno v čl. 10 odst. 3 Listiny základních práv a svobod („LZPS“ $\left.{ }^{97}\right]$ obvykle spojováno s možností jednotlivce rozvíjet se a seberealizovat se v lidské společnosti, ${ }^{98}$ lze jej chápat i jinak. Právo na informační sebeurčení (stejně jako právo na soukromí obecně ${ }^{99}$ ) v sobě totiž obsahuje nejen složku externí, pod níž si můžeme představit možnost kontroly, jaké informace, komu, za jakých okolností a jakým způsobem jsou šířeny a sdíleny (o čemž bude pojednávat další podkapitola). Obsahuje i složku interní, která existuje sama o sobě, bez ohledu na interakci s jinými lidmi. Tou je předpoklad pro individuální sebeurčení jednotlivce, tedy jeho vnitřní kapacita pro sebeuvědomění a sebedefinici, a dále možnost prožití života v souladu se svou vlastní vůlí. Jednoduše řečeno, informační sebeurčení (resp. soukromí) v sobě zahrnuje předpoklad pro existenci lidí jakožto individuálních osobností, jejichž lidství je respektováno. ${ }^{100}$ Právě v tomto ohledu může vytváření deepfake pornografie představovat zásah do práva na informační sebeurčení, nebot tento respekt $\mathrm{k}$ sebeurčení jiných lidí (kteří nechtějí být $\mathrm{v}$ pornografickém videu vyobrazeni) narušuje.

97 Usnesení předsednictva České národní rady č. 2/1993 Sb., o vyhlášení Listiny základních práv a svobod jako součásti ústavního pořádku České republiky, ve znění ústavního č. zákona 162/1998 Sb.

98 Srov. rozhodnutí Spolkového ústavního soudu SRN ze dne 15. 12. 1983, BVerfGE 65, 1, body 94-97. In: OpenJur [online]. 2012 [cit. 29. 4. 2020]. Dostupné z: https:// openjur.de/u/268440.html

99 WAGNEROVÁ, Eliška. Právo na soukromí: Kde má být svoboda, tam musí být soukromí. In: ŠIMÍČEK, Vojtěch (ed.). Právo na soukromí. Brno: Masarykova univerzita, 2011, s. 54.

${ }^{100} \mathrm{~K}$ tomu bliže vit REIMAN, Jeffrey H. Privacy, Intimacy and Personhood. Philosophy and $\mathrm{Pu}$ blic Affairs [online]. 1976, roč. 6, 1 [cit. 26. 9. 2020], s. 38-44. Dostupné z: https:// www.jstor.org/stable/2265060?seq $=1$ 
Vytvoření pornografického deepfake videa může dále zasahovat do práv na ochranu osobnosti člověka ve smyslu § 81 až $§ 90$ zákona č. 89/2012 Sb., občanského zákoníku (jejichž ústavní garance má rovněž oporu v čl. 10 LZPS). Konkrétně se tento zásah může projevovat manipulací s volně dostupnými fotografiemi za účelem vytvoření konkrétního videa. Tímto způsobem však dochází $\mathrm{k}$ zásahu spočívajícího primárně v tom, že byla nedovoleně užita podoba určité osoby, nikoliv v tom, že byla užita právě pro vytvoření pornografického deepfake. Autorka tohoto článku se tedy přiklání $\mathrm{k}$ závěru, že pouhé vytvoření takového umělého pornografického videa zobrazujícího konkrétní osobu nepředstavuje o mnoho větší zásah než jakékoliv jiné nedovolené nakládání s její podobou, a to i přesto, že ji výsledné video zobrazuje v sexuálně explicitních scénách. Pokud však výsledné video není dále jakkoliv šířeno, může být považováno toliko za oplzlé či nemorální, ${ }^{101}$ avšak nepředstavuje takový zásah do práv osoby $\mathrm{v}$ něm vyobrazené, jako je tomu $\mathrm{v}$ př́ípadě jiných typů IBSA. I s ohledem na to, že se o něm obět (anebo kdokoliv jiný) vůbec nemusí dozvědět, se vytvoření pornografického deepfake, které není dále šǐřené nebo zpřístupněné, v podstatě příliš neliší od sexuálních fantazií, které jednotlivec může mít ohledně jiných lidí. ${ }^{102}$ Tento závěr je nicméně otevřen širší diskuzi, která může být ovlivněna dalším rozvojem pornografických deepfake videí a způsobu jejich vytváření.

V kontextu vytváření těchto videí nelze dále pominout to, že vytvořené pornografické deepfake video nemusí vždy sloužit pouze k sexuální gratifikaci jeho tvůrce - může být samozřejmě užito i za účelem vydírání zobrazené osoby, a to vyhrožováním jeho uveřejnění. ${ }^{103}$ Tím spíš, pokud by obět vyobrazovalo obzvlášt ponižujícím způsobem, např. v extrémně násilné, pedofilní či zoofilní pornografické nahrávce. ${ }^{104}$ Takové jednání spadá mezi jiné formy IBSA popsané výše (zejména „sextortion“) a zároveň svou

\footnotetext{
${ }^{101}$ HARRIS, s. 125.

${ }^{102}$ ÖHMAN, Carl. Introducing the pervert's dilemma: a contribution to the critique of Deepfake Pornography. Ethics and Information Technology [online]. 2019 [cit. 29. 4. 2020]. Dostupné z: https://link.springer.com/article/10.1007/s10676-019-09522-1

${ }^{103}$ HARRIS, op. cit., s. 102.

${ }^{104}$ Srov. CHESNEY, CITRON, op. cit., s. 1773.
} 
povahou zasahuje do trestněprávní roviny. $\mathrm{V}$ takovém př́ípadě však $\mathrm{k}$ tomuto odvozenému zásahu dochází až vydíráním vyobrazené osoby, nikoliv samotným vytvořením daného videa. $Z$ hlediska existence pornografického deepfake videa tedy zpravidla dochází $\mathrm{k}$ významnému zásahu do individuálních práv až v okamžiku, kdy jej může zhlédnout někdo jiný.

\subsection{ZVEŘEJNĚNÍ, SDÍLENÍ ČI ŠÍŘENÍ PORNOGRAFICKÉHO DEEPFAKE}

Na tomto místě je důležité si uvědomit, že aby pornografické deepfake zasahovalo do práv vyobrazené osoby, není nutno, aby bylo nutně šířeno veřejně. Stejně jako u jiných výše popsaných druhů revenge porn ke vzniku újmy postačí, je-li sdíleno kupříkladu ve skupině známých, v určitém úzkém kolektivu (školním, pracovním apod.), či je-li zasláno vybraným osobám jako třeba zaměstnavateli anebo klientovi dotyčné osoby. Taková forma může být $s$ ohledem na okolnosti pro většinu lidí zpravidla dokonce horší, než kdyby se pornografické deepfake video s nimi jako aktéry šírilo internetem anonymně, a pravděpodobnost rozpoznání by tak byla nižší (což samozřejmě neplatí $\mathrm{v}$ případě známých celebrit).

$\mathrm{V}$ první řadě je nutno zdůraznit, že šíření falešného pornografického deepfake videa představuje citelný zásah do lidské důstojnosti. Lidská důstojnost je totiž bezpochyby narušena tehdy, je-li šîren videozáznam vyobrazující člověka, jehož podoba na nahrávce činí více či méně obscénní akty, $\mathrm{k}$ nimž tento skutečný člověk neudělil souhlas. Jedním z důvodů, které mohou v tomto směru vyobrazenému člověku způsobit újmu, je možnost vidět sám sebe (resp. svou podobu) vykonávat činnosti, které by normálně nevykonával, anebo by je nevykonával zpodobněným způsobem, př́padně $s$ konkrétním člověkem (jiným aktérem původního pornografického videa). V tomto směru se zásah do lidské důstojnosti do určité míry prolíná s výše popsaným právem na informační sebeurčení, nebở je tímto způsobem s člověkem (resp. jeho podobou) nakládáno jako s objektem, nikoliv subjektem. Pokud osoba, která je v deepfake pornu vyobrazena, nikdy žádné pornografické video nenatočila, představuje její „vložení“ do takového uměle vytvořeného videa nerespektování volby dané osoby neúčinkovat 
v pornografickém videu, které je př́stupné jiným lidem. ${ }^{105}$ Tímto způsobem je narušována kontrola jednotlivců nad tím, zdali budou, anebo nebudou vyobrazeni při sexuálních aktivitách. Možnost jejich sebeurčení a „vlastnění“ sebe sama (konkrétně své podoby) před ostatními lidmi je značně zasažena, kvůli čemuž je tak nutně zasažena i jejich lidská důstojnost.

Samozrejmě se nabízí otázka, nakolik závažný zásah do práv vyobrazeného člověka deepfake pornografie skutečně představuje. Nelze totiž zapomínat na to, že se jedná o uměle vytvořená videa - videomontáže - která jsou do určité míry srovnatelná s profesionálními fotomontážemi (opomeňme na okamžik, že i fotomontáže mohou představovat zásah do práv člověka). Zaprvé, je třeba si uvědomit, že se může jednat o velmi kvalitně a realisticky zpracované videomontáže, jejichž uvěritelnost bude s vývojem užívaných technologií větší a větší. Už dnes tak může být těžké rozlišit, která pornografická videa jsou skutečná (a osoby na nich vyobrazené je za účelem zveřejnění natočily vědomě a dobrovolně, pokud se nejedná o revenge porn či záznam sexuálního napadení) a která jsou uměle vytvořená. Tím spíše, že se jedná o nový fenomén, tudíž nejsme doposud zvyklí u realisticky se tvárících videí kriticky přemýšlet nad jejich pravdivostí (a nutno dodat, že v segmentu pornografie to pro mnohé diváky ani není podstatné). Právě realističnost a uvěřitelnost výsledného videa je tím nejproblematičtějším a nejvážnějším aspektem technologie deepfake, a tedy i deepfake pornografie. Tento aspekt ale současně představuje důvod jejího úspěchu. Věř́me tomu, co vidíme ${ }^{106}$ - a pokud vidíme video (tedy nikoliv jeden statický snímek, který lze v grafických programech upravit snadno), které pů-

\footnotetext{
${ }^{105}$ Je možno se zamyslet, zdali by bylo stejně závažným zásahem do lidské důstojnosti vytvoření pornografického deepfake videa, do něhož by byla vložena „hlava“ jiné pornoherečky, která běžně taková videa natáčí. Je to samožrejmě diskuzní otázka, autorka tohoto článku se nicméně domnívá, že $\mathrm{v}$ takovém případě by se rovněž o zásad do lidské důstojnosti jednalo, avšak byl by menší. Spočíval by zřejmě pouze $\mathrm{v}$ tom, že autor daného videa vyobrazenou pornoherečku objektivizoval a zobrazil ji způsobem, který nerespektuje její individualitu (to, jak v pornografických videích skutečně vystupuje). Odlišný případ by však pravděpodobně nastal tehdy, pokud by autor tuto pornoherečku nechal „účinkovat“ např. v pedofilním, zoofilním anebo jinak problematickém pornu, pokud daný druh videí netočí a nikdy netočila. Takový př́ípad by mohl představovat zásah do lidské důstojnosti srovnatelný s tím, pokud by vyobrazenou osobou byl kdokoliv jiný.
} 
sobí autenticky, nevykazuje známky parodie či zfalšování a pravdivost jeho obsahu není přinejmenším nepředstavitelná, není těžké mu uvěřit. ${ }^{107}$

$S$ tím souvisí i způsob, jakým se zveřejnění či šíření pornografických deepfakes dotýká práva na soukromí. Skutečnost, že jiní lidé mohou takové video zhlédnout a případně mu uvěřit, vážně zasahuje do osobnostních práv ve smyslu čl. 10 odst. 1 LZPS, tedy konkrétně práva na ochranu cti, dobré pověsti a jména člověka (která spadají pod ochranu soukromí largo sensu). Ústavní soud ve své judikatư̌e dovodil, že tyto chráněné hodnoty představují důležitou a integrální součást důstojnosti člověka (ve smyslu jeho váženosti) a formují základ mnoha rozhodnutí činěných členy demokratické společnosti. Jsou-li jednou pošpiněny, mohou být poškozeny navždy, obzvlášt není-li dotyčnému dána možnost rehabilitace. ${ }^{108}$ Právě neefektivita této možnosti obětem deepfake pornografie nejvíce ztěžuje nastalou situaci, nebot si lze jen těžko představit, že by mohly oběti ve snaze o nápravu vlastní cti a pověsti přesvědčovat každého, kdo „jejich“ video zhlédl, že není skutečné. Naopak si ale lze představit, že tato forma pošpinění cti a dobré pověsti určité osoby může mít dopad nejen do individuálních práv, ale i do kolektivních zájmů společnosti. ${ }^{109}$ Může totiž mj. vést i k ovlivnění výsledků voleb a jiných politických procesů, a tedy fungování demokracie jako takové. ${ }^{110}$ Pokud by se např. před volbami objevilo pornografické video, $\mathrm{v}$ němž by figuroval některý $\mathrm{z}$ kandidátů (prav-

${ }^{106} \mathrm{~K}$ zastaralosti fráze „uvěřím, až to uvidím na vlastní oči“ blíže viz HALL, Holly Kathleen. Deepfake Videos: When Seeing Isn't Believing. Catholic University Journal of Law and Technology [online]. 2018, roč. 27, 1 [cit. 27. 9. 2020], s. 51-76. Dostupné z: https://scholarship.law.edu/cgi/viewcontent.cgi?article $=1060 \&$ context $=$ jlt

${ }^{107}$ Podle výzkumů patří mezi faktory zvyšující uvěřitelnost falešných deepfake videí (nikoliv konkrétně pornografických) plynulost videa způsobená realističností dané technologie a známost vyobrazené osoby. K tomu blíže viz VACCARI, Christian; CHADWICK, Andrew. Deepfakes and Disinformation: Exploring the Impact of Synthetic Political Video on Deception, Uncertainty, and Trust in News. Social Media + Society [online]. 2020, roč. 6, 1 [cit. 27. 9. 2020], s. 2. Dostupné z: https://journals.sagepub.com/doi/pdf/10.1177/ 2056305120903408

${ }^{108}$ Nález Ústavního soudu ze dne 11. 11. 2005, sp. zn. I. ÚS 453/03, část IV.

${ }^{109} \mathrm{~K}$ tzv. „kolektivní újmě“ nebo „kulturní újmě“ způsobené nekonsenzuální pornografií srov. MCGLYNN, RACKLEY, op. cit., s. 544, 549-551, 561.

${ }^{110}$ Na možnost ovlivňování výsledků voleb prostřednictvím (nikoliv přímo pornografických) deepfake videí upozorňují Citron a Chesney. Viz CHESNEY, CITRON, op. cit., s. 22-23. 
děpodobně spíše kandidátka s ohledem na genderovou nevyrovnanost IBSA), je možné, že by se určitá část voličů rozhodla jej z těchto důvodů nevolit - a to bez ohledu na to, že by se jednalo o uměle vytvořené manipulativní deepfake video. ${ }^{111}$

Z hlediska zásahu do osobní cti a dobré pověsti člověka je potřeba se ještě krátce zamyslet nad následujícím: byl by zásah do těchto práv osoby vyobrazené na zveřejněném nebo jinak šířeném deepfake pornografickém videu stejně velký, pokud by jeho autor zároveň uvedl, že je dané video falešné, tedy uměle vytvořené (a šírí jej např. za účelem pomsty)? Bezpochyby by i v tomto př́padě bylo možno hovořit o zásahu do lidské důstojnosti - vyobrazená osoba by byla objektivizována, byla by narušena možnost jejího individuálního sebeurčení neúčinkovat $\mathrm{v}$ pornografických videích a mohla by vidět „sama sebe“ při obscénních činnostech. Je však představitelné, že zásah do její cti a dobré pověsti by byl umenšen přiznáním nepravdivosti daného videa. ${ }^{112}$

Vedle zásahu do uvedených osobnostních práv je samozřejmě potřeba se zabývat i tím, jakým způsobem zveřejnění, sdílení či šǐření pornografického deepfake videa zasahuje do soukromí vyobrazené osoby stricto sensu. Předně dochází společně se šiřrením vytvořeného videa i k neoprávněnému šǐření její podoby (viz § 85 odst. 1 občanského zákoníku). Otázkou je, zdali je

${ }^{111}$ Obdobné situaci čelila americká kandidátka na prezidentku Hillary Clinton v roce 2016. Na několika pornografických stránkách se objevilo video (nikoliv deepfake, tato technologie tou dobou ještě neexistovala), které ji mělo údajně vyobrazovat při sexu v hotelovém pokoji s černošským mužem, přičemž bylo video doplněno popisky jako „takto Hillary Clinton získává černošské hlasy“. Video údajně nepưsobilo př́liš autentickým dojmem a ti, kteří jej zhlédli, byli skeptičtí vůči tomu, že by se skutečně jednalo o Hillary Clinton. Pokud by se jednalo o deepfake video, jeho autentičnost by mohla být výrazně větší, a kredibilita kandidátky naopak o poznání menší. Je nutno zároveň v tomto kontextu dodat, že není prokázáno, že by šîrení tohoto videa (které je dodnes na internetu dohledatelné) způsobilo následné vítězství Donalda Trumpa. Bylo však naopak prokázáno, že za šířením videa stála ruská agentura Internet Research Agency. Viz COLLINS, Ben. Russia-linked account pushed fake Hillary Clinton sex video. In: NBC News [online]. 11. 4. 2018 [cit. 29. 4. 2020]. Dostupné z: https://www.nbcnews.com/tech/security/russia-linked-account-pushed-fakehillary-clinton-sex-video-n864871

112 Záměrně se zde neuvádí, že by $\mathrm{k}$ němu vůbec nedošlo - jak je popsáno výše $\mathrm{v}$ tomto článku, internet nezapomíná. Lze tedy předpokládat že by se takové video šírilo i dále, mimo rámec jeho původního sdílení. $\mathrm{K}$ zásahu do těchto práv by tak $\mathrm{v}$ budoucnu mohlo dojít, pokud by zveřejněné video zhlédl a uvěřil mu někdo, kdo o jeho kontextu nic neví. 
však zásah do soukromí jednotlivce větší proto, že je jeho podoba vyobrazena právě v pornografickém videu, anebo zdali hranice zásahu do soukromí $\mathrm{v}$ tomto směru končí právě neoprávněným nakládáním s podobou konkrétní oběti. Autorka tohoto článku se domnívá, že zásah do soukromí jedince je větší právě kvůli tomu, že se jedná o jeho vyobrazení v pornografickém videu. Tento jedinec, resp. jeho podoba, je ve výsledném videu nucen velmi objektivizujícím způsobem činit něco, co se běžně odehrává „za zavřenými dveřmi“ a co je samotnou podstatou lidské intimity a sexuality. Zahraniční odborná literatura v tomto kontextu dokonce hovoří o zásahu do „sexuální autonomie a sexuálního projevu,“113 „sexuální integrity a identity“ “114 či „sexuálního soukromí“. ${ }^{115}$ Deepfake pornografie tak způsobuje zásah do samotného jádra pojmu soukromí, ${ }^{116}$ a to do tzv. „nejintimnější osobní sféry jednotlivce“ ve smyslu judikatury ESLP. ${ }^{117}$ Jak již totiž bylo zmíněno, soukromí má i interní složku, která se nejvíce projevuje v osobní soukromé sféře. ${ }^{118}$ Podle ESLP mohou do této osobní sféry jednotlivce (chráněné čl. 8 Úmluvy o ochraně lidských práv a základních svobod ${ }^{119}$ ) spadat mj. i aspekty sociální identity a sexuálního života člověka. ${ }^{120}$ Podle Ústavního soudu

${ }^{113}$ MCGLYNN, RACKLEY, op. cit., s. 548-549.

114 ŠEPEC, Miha. Revenge Dissemination of Sexually Explicit Material as a Sexual Offence or as a Privacy Violation Offence Pornography or Non-Consensual. International Journal of Cyber Criminology [online]. 2019, roč. 13, 2 [cit. 29. 4. 2020], s. 421. Dostupné z: https://www.cybercrimejournal.com/MihaSepecVol13Issue2IJCC2019.pdf

115 CITRON, op. cit., s. 1874.

${ }^{116}$ Pro určení toho, co lze ještě interpretovat jako „soukromí“, slouží podle Michala Bartoně vazba na ochranu lidské důstojnosti jako zachování určující meze - existuje tak blízký vztah mezi ochranou soukromí a ochranou lidské důstojnosti. BARTOŇ, Michal a kol. Základní práva. Praha: Leges, 2016, s. 284.

117 Rozsudek Evropského soudu pro lidská práva ze dne 22. 10. 1981. Dudgeon vs. Spojené království, op. cit., bod 52.

${ }^{118}$ Srov. WAGNEROVÁ, Eliška. Právo na soukromí v širším smyslu. In: WAGNEROVÁ, Eliška a kol. Listina základních práv a svobod: komentár̆. Praha: Wolters Kluwer ČR, 2012, s. 282.

119 Úmluva o ochraně lidských práv a základních svobod Rady Evropy ze dne 4. 11. 1950, ve znění Protokoli̊ 11 a 14, s Protokoly 1, 4, 6, 7, 12 a 13. In: Evropský soud pro lidská práva [online]. Evropský soud pro lidská práva [cit. 30. 4. 2020]. Dostupné z: http://www.echr.coe.int/Documents/Convention_CES.pdf

${ }^{120}$ Rozsudek Evropského soudu pro lidská práva ze dne 4. 12. 2008. S. a Marper vs. Spojené království. ECHR 30562/04 a 30566/04. In: HUDOC [online]. Evropský soud pro lidská práva [cit. 29. 4. 2020], bod 66. Dostupné z: http://hudoc.echr.coe.int/eng?i=001-90051 
navíc spadají pod rozsah tzv. nejintimnější sféry jednotlivce i informace o sexualitě člověka. Ve vztahu k této nejintimnější sféře se navíc zvyšuje míra ochrany soukromí a důstojnosti, ${ }^{121}$ což souvisí s tím, o jak citlivou oblast se jedná a $\mathrm{k}$ nakolik závažné újmě může zásahem do této sféry dojít.

Přirozeně se nabízí namítnout, že ze skutečného „soukromí“ osoby vyobrazené v pornografickém deepfake je uveřejněna pouze její podoba (hlava). Oproti jiným případům IBSA není např. vyobrazeno reálné nahé tělo oběti anebo není obět vyobrazena při konkrétních sexuálních aktivitách, které by skutečně vykonávala. Je třeba jasně zdůraznit, že šíření skutečného pornografického videa vyobrazující osobu, která k takovému jednání nedala souhlas, představuje bezpochyby zásadně větší zásah do jejího soukromí, než je tomu v př́ipadě falešných deepfakes. Bylo by však chybou domnívat se, že v jejich př́ípadě není soukromí jednotlivce vůbec zasaženo. Jak již bylo zmíněno, jedním z aspektů práva na soukromí je totiž i právo na informační sebeurčení. Jak konstatoval německý Spolkový soud, který v roce 1983 tento koncept představil, nemá-li jedinec jistotu, jaké informace jsou o jeho osobě sdělovány, ovlivňuje taková skutečnost svobodu jeho rozhodování o sobě samém. ${ }^{122}$ Ústavní soud v nálezu ze dne 22. 3. 2011, sp. zn. Pl. ÚS 24/10, zároveň potvrdil, že obecnou funkcí práva na respekt k soukromému životu je možnost zajistit prostor pro rozvoj a realizaci individuální osobnosti. Ztráta kontroly nad informacemi, které jsou o nás dostupné, by však takové možnosti seberealizace ve společnosti zabránila. $^{123}$

To lze vztáhnout i na šíření uměle vytvořených pornografických deepfake videí, která se jeví být skutečným záznamem dotyčné osoby. Tato videa totiž zasahují do toho, jak se dané osoby chtějí realizovat a jak se chtějí prezentovat na veřejnosti. Autorka tohoto článku se domnívá, že v případě

\footnotetext{
${ }^{121}$ Nález Ústavního soudu ze dne 20. 12. 2016, sp. zn. Pl. ÚS 3/14.

${ }^{122}$ Rozhodnutí Spolkového ústavního soudu SRN ze dne 15. 12. 1983, BVerfGE 65, 1, op. cit., bod 94.

${ }^{123}$ Srov. ROUVROY, Antoinette; POULLET, Yves. The Right to Informational Self-Determination and the Value of Self-Development: Reassessing the Importance of Privacy for Democracy. In: GUTWIRTH, Serge et kol. (ed.). Reinventing Data Protection? [online]. Dordrecht: Springer, 2009, s. 51. Dostupné z: https://link.springer.com/chapter/10.1007/978-14020-9498-9_2
} 
deepfake pornografie - právě s ohledem na citelnost a povahu jejích dopadů na život vyobrazené osoby - je namístě ochranu vztáhnout i na úzce chápaný pojem soukromí, a to konkrétně ve smyslu sexuálního soukromí. Zaprvé, jak je uvedeno výše, tato oblast soukromí podléhá zvýšené miřre právní ochrany. Zadruhé, zveřejnění deepfake pornografického videa může nejen snižovat osobní čest a dobrou pověst na něm vyobrazené osoby, ale zejména učiní otázku jejího sexuálního života „veřejným tématem“. ${ }^{124}$ Tato osoba tak pravděpodobně bude (ve snaze vyvrátit pravdivost videa) nucena hovořit o svém sexuálním životě s lidmi, jimž by tuto oblast vlastního soukromí normálně neodhalovala, anebo způsobem, jakým by tak běžně nečinila. $\mathrm{V}$ tomto směru se deepfake pornografie liší od jiných druhů deepfake videí - i tato ostatní videa (např. falešné politické projevy) mohou zásadně zasáhnout do osobnostních práv člověka, který se stal jejich obětí, a jeho váženost může být významně zasažena. Zřejmě však nebude vzniklou újmu vnímat natolik niterně, jako pokud bude v důsledku zveřejnění „jeho“ deepfake porna veřejně rozviřrena otázka projevů jeho sexuality. A již popsaná realističnost a explicitnost tohoto typu videí tento dopad zásadně zesiluje.

Jelikož deepfake pornografie nepředstavuje reálné záznamy skutečných lidí, liší se od ostatních typů IBSA právě v tom, že se její obětí může stát prakticky kdokoliv. Jak se tedy proti ní lze bránit?

\subsection{PROSTŘEDKY OBRANY PROTI PORNOGRAFICKÝM DEEPFAKES}

Na tomto místě je nejprve je třeba uvést, že $\mathrm{z}$ důvodu absence české odborné literatury $\mathrm{k}$ tomuto tématu anebo soudně řešených př́padů jsou dále popisované prostředky ochrany pouze předpokládané, doposud neozkoušené. Jelikož však lze očekávat, že se i v České republice v dohledné době tyto př́pady objeví (stejně jako se zde objevují jiné formy revenge porn), pokusí se autorka na tomto místě shrnout možnosti, kterými se teoreticky lze proti deepfake pornografii bránit. $\mathrm{V}$ mnohém se jedná o stejné nástroje, které mohou sloužit i k ochraně proti jiným formám nekonsenzuální porno-

\footnotetext{
${ }^{124}$ Nejenom ve smyslu „celospolečenským tématem“, postačí, bude-li toto téma určitým způsobem rezonovat v kolektivu přátel, kolegů, známých apod. vyobrazené osoby.
} 
grafie. A bohužel je potřeba dodat, že se nejedná o př́liš efektivní prostředky obrany. ${ }^{125}$

Jedním z nich může být civilní žaloba na ochranu osobnosti, a to zejména ve smyslu práva na ochranu podoby a soukromí (ve smyslu § 84 až § 90 občanského zákoníku). Jeho obsahem je jednak zákaz zásahu do soukromí jiného člověka, a to mj. pořizováním, využíváním anebo šířením záznamů o jeho soukromém životě. Obsahem práva na ochranu podoby člověka pak je zákaz zachycení podoby a další nakládání s ní bez svolení vyobrazené osoby. Judikatura Nejvyššího soudu v tomto směru vymezuje jak pozitivní komponentu tohoto práva (dispoziční právo každé osoby zachytit svou podobu a udělovat jiným osobám souhlas k jejímu zachycení), tak i negativní (možnost bránit se proti neoprávněnému zachycení podoby, právě tak jako proti jejímu neoprávněnému rozšiřování ze strany jiného subjektu). ${ }^{126}$ Oproti jiným případům nekonsenzuální pornografie, kdy může být vyobrazeno např. pouze tělo, nikoliv obličej (a osoba je tedy na základě této podoby hůře identifikovatelná ${ }^{127}$ ), je v př́ípadě oběti pornografického deepfake vyobrazena právě jen její tvář. Tato osoba je tudíž rozpoznatelná velmi snadno. Rozhodne-li se proti tomu, kdo vytvořené deepfake video šírí, bránit touto cestou, může se dožadovat a) upuštění od neoprávněného zásahu do individuálních práv (žaloba negatorní), b) odstranění závadného stavu (žaloba restituční) a c) náhradu škody a nemajetkové újmy včetně uzpůsobených duševních útrap (žaloba satisfakční). ${ }^{128}$

V úvahu samozřejmě dále připadá i rovina trestního práva. V př́ípadě zveřejnění, šíření anebo sdílení pornografického deepfake videa lze uvažovat o naplnění skutkové podstaty trestného činu poškození cizích práv podle § 181 zákona č. 40/2009 Sb., trestního zákoníku. Samotná podstata deepfake pornografie totiž spočívá ve snaze vyvolat dojem, že vyobrazený

\footnotetext{
${ }^{125}$ K tomu blíže viz DVOŘÁKOVÁ, op. cit., s. 55-80.

${ }^{126}$ Rozsudek Nejvyššího soudu ze dne 27. 5. 2015, sp. zn. 30 Cdo 5216/2014.

${ }^{127}$ Podle názoru autorky v případě revenge porn $\mathrm{k}$ zásahu do práv jednotlivce dojde $\mathrm{i}$ tehdy, jsou-li sdíleny záznamy, na nichž není vidět hlava dotyčného. Byt samožrejmě bude takový zásah pro daného člověka méně nepř́ijemný (lidé, kteří neznají jeho nahé tělo, jej nebudou schopni rozpoznat), právně relevantní přesto bude. K tomu blíže viz DVOŘÁKOVÁ, op. cit., s. 58.

${ }^{128} \S 82$ a § 2956 občanského zákoníku. Tyto nároky lze požadovat i společně.
} 
uměle vytvořený záznam je skutečný, $v$ důsledku čehož může být tímto jednáním naplněna zákonná podmínka „uvedení někoho v omyl““ ${ }^{129}$ Případně může připadat $\mathrm{v}$ úvahu naplnění skutkové podstaty trestného činu pomluvy podle $\S 184$ trestního zákoníku, pokud by bylo šírené deepfake pornografické video považováno za „sdèlení nepravdivého údaje, který je zpưsobilý značnou měrou ohrozit vážnost [dotyčného jedince] u spoluobčanů, zejména poškodit jej $v$ zaměstnání, narušit jeho rodinné vztahy nebo způsobit mu jinou vážnou újmu“. ${ }^{130}$ Pokud by vytvořené deepfake video znázorňovalo např̀. zoofilní anebo pedofilní pornografii, bylo by dále na místě aplikovat § 191 (šiřrení pornografie) a § 192 (výroba a jiné nakládání s dětskou pornografií) trestního zákoníku. Stejně tak by bylo možno shledat naplnění jiných skutkových podstat, pokud by byla osoba např. vydírána ze šíření deepfake pornografie, která by ji vyobrazovala. To už se však poněkud míjí se samotnou podstatou zkoumané problematiky. $\mathrm{Z}$ uvedených důvodů je tedy autorka tohoto článku pevně přesvědčená, že by bylo vhodnější a systematičtější, pokud by byl trestní zákoník rozšîřen o nové skutkové podstaty, které by výslovně pokrývaly problematiku IBSA a zdůrazňovaly specifický zásah do sexuálního soukromí jednotlivce. $\mathrm{K}$ tomuto názoru ji vede především skutečnost, že zahraniční právní úpravy již v uplynulých letech na rozšîrení revenge porn reagovaly jeho kriminalizací, ${ }^{131}$ a mnozí odborníci zdůrazňují, že je třeba obdobně postupovat i v př́ípadě deepfake pornografie. $^{132}$

Vzhledem k tomu, že se však pornografická deepfake videa (stejně jako jiné druhy nekonsenzuální pornografie) šǐrí internetem lavinovitě a nejsou

${ }^{129}$ Tato skutková podstata je nejčastěji užívána i v jiných př́ípadech revenge porn. K tomu viz DVOŘÁKOVÁ, op. cit., s. 74-75.

${ }^{130} \mathrm{~V}$ tomto kontextu přichází samozřejmě v úvahu otázka svobody projevu a její případná kolize s individuálními právy jiné osoby. Tento článek se tomu podrobněji věnovat nebude, k tomu srov. DVOŘÁKOVÁ, op. cit., s. 46-53. Blíže se této otázce přímo ve vztahu k pornografickým deepfakes věnují FRANKS, Mary Anne; WALDMAN, Ari Ezra. Sex, Lies, and Videotape: Deep Fakes and Free Speech Delusions. Maryland Law Review [online]. 2019, roč. 78,4 [cit. 29. 4. 2020]. Dostupné z: https://digitalcommons.law.umaryland.edu/cgi/ viewcontent.cgi? article $=3835 \&$ context $=\mathrm{mlr}$

${ }^{131}$ Např. Izrael, Spojené království, Kanada, Francie anebo mnohé státy Spojených států amerických. Srov. DVOŘÁKOVÁ, op. cit., s. 81-82.

${ }^{132} \mathrm{~K}$ tomu viz DELFINO, op. cit., HARRIS, op. cit., anebo FRANKS, WALDMAN, op. cit. 
omezena na území České republiky, je nutno se zabývat i prostředky obrany, které lze najít na nadnárodní úrovni. Těmi jsou v rámci Evropské unie zejména právo být zapomenut ${ }^{133,134}$ anebo požadavek vưči provozovateli internetové stránky na odstranění pornografického deepfake videa (tzv. „notice and take down"), které se na ní vyskytuje. ${ }^{135,136}$ Nicméně nejúčinnějšími prostředky proti této formě IBSA stejně bezesporu je, pokud provozovatelé internetových stránek (zejména sociálních sítí anebo pornografických webů) brání uveřejňování pornografických deepfakes svými vlastními prostř̌edky, jako tak činí např. Facebook, ${ }^{137}$ Reddit, Twitter anebo Pornhub. ${ }^{138}$ To však nemůže zabránit jejich šiřrení jinými prostředky.

Na závěr této kapitoly je vhodno ještě dodat, že se v poslední době objevily i různé další návrhy, jak lze nedovolenému šíření deepfake porna zabránit. Jedním z těchto návrhů je např. úvaha o vytvoření „feministické aplikace“ pro vytváření pornografických deepfake videí, která by umožňovala na jedné straně za finanční odměnu nahrávat vlastní "face sety“ (soubor fotografií), a na druhé straně na základě těchto datasetů vytvářet

\footnotetext{
${ }^{133}$ Ve smyslu čl. 17 nařízení Evropského parlamentu a Rady (EU) 2016/679 ze dne 27. 4. 2016 o ochraně fyzických osob v souvislosti se zpracováním osobních údajů a o volném pohybu těchto údajů a o zrušení směrnice 95/46/ES In: EUR-lex [právní informační systém]. Úřad pro publikace Evropské unie. Dostupné z: https://eur-lex.europa.eu/ legal-content/CS/TXT/PDF/?uri=CELEX:32016R0679\&from=CS, a dále ve smyslu rozsudku Soudního dvora (velkého senátu) ze dne 13. 5. 2014 ve věci C-131/12, Google Spain and Google.

${ }^{134} \mathrm{~K}$ tomu srov. např. MESARČíK, Matúš; ZIMEN, Ondrej. Deep fakes a ochrana súkromia. Acta Facultatis Iuridicae Universitatis Comenianae [online]. 2019, roč. 38, 2 [cit. 29. 4. 2020]. Dostupné z: https://afi.flaw.uniba.sk/index.php/AFI/article/view/65

${ }^{135}$ Ve smyslu čl. 14 směrnice Evropského parlamentu a Rady 2000/31/ES ze dne 8. 6. 2000 o některých právních aspektech služeb informační společnosti, zejména elektronického obchodu, na vnitřním trhu. In: EUR-lex [právní informační systém]. Úřad pro publikace Evropské unie. Dostupné z: https://eur-lex.europa.eu/legal-content/CS/TXT/PDF/?uri=CELEX:32000L0031\&from $=$ EN

${ }^{136}$ Ve vnitrostátním právu je pak tzv. „notice and take down“ systém upraven $\S 5$ odst. 1 písm. b) zákona č. 480/2004 Sb., o některých službách informační společnosti, který uvedenou směrnici 2000/31/ES implementuje.

${ }^{137}$ Facebook nezakázal pouze pornografická deepfakes, ale veškerá takto uměle vytvořená videa. Viz SHEAD, Sam. Facebook to ban 'deepfakes'. In: BBC [online]. 7. 1. 2020

[cit. 29. 4. 2020].Dostupné z: https://www.bbc.com/news/technology-51018758

${ }^{138}$ HARRIS, op. cit., s. 101-102.
} 
konsenzuální pornografická deepfakes. ${ }^{139}$ Dalším návrhem je určitá forma „digitálního podpisu“, který by se vepsal do jakéhokoliv natočeného videa. Podle toho by bylo možno poznat, je-li nahrávka autentická, anebo byla dále měněna či uměle spojena s jinou. ${ }^{140}$ Oba tyto návrhy však mohou fungovat jen v případě, kdy tvůrce anebo „divák“ bude dbát o to, aby nedošlo $k$ zásahu do ničích práv. $Z$ toho důvodu je jejich využití pro boj s nekonsenzuální pornografií spíše nepravděpodobné a obětem této nové formy IBSA př́liš nepomůže.

\section{ZÁVĚR}

Nekonsenzuální pornografie může mít mnoho podob, a to od pořízení fotografie nahého člověka prostřednictvím skryté kamery pro osobní účely, až po zveřejnění a sdílení videozáznamu znásilnění. Co mají tyto jednotlivé formy společného, je to, že mohou mít $\mathrm{v}$ různé míře závažnosti obdobný dopad na život oběti jako skutečný sexuální útok, a to i přes svou „nefyzickou“ formu. Jedná se tedy o nekontaktní sexuální násilí, které lze dokonce označit za formu sexuálního zneužitíi ${ }^{141}$ („,image-based sexual abuse“). Mezi těmito druhy jednání se značně vymyká rozvoj deepfake pornografie, která se objevila v roce 2017 a velmi rychle se rozšírila. Jejím prostřednictvím lze jednak vytvářet falešná, avšak realistická pornografická videa znázorňující ženy, kterým chce tvưrce takového záznamu ublížit z osobních důvodů, dále slavné ženy, které si internetoví uživatelé přejí vidět nahé, anebo např. političky, které má takové video zdiskreditovat. Důvodů samozřejmě může být nespočet a tato nová technologie $\mathrm{k}$ jejich naplnění poskytuje velmi snadný způsob. Právní aspekty deepfake porna se v zahraničních odborných kruzích v uplynulých měsících hojně diskutují. České republice se však doposud tyto otázky vyhýbají - nutno podotknout, že zřejmě i proto, že se jí prozatím vyhýbá existence popsaného problému jako takového.

\footnotetext{
${ }^{139}$ Více viz RAFFAGHELLO a kol., op. cit.

${ }^{140}$ LIN, Herb; HOLLAND, Hank J. The Danger of Deepfakes: Responding to Bobby Chesney and Danielle Citron. In: Lawfare [online]. 27. 2. 2018 [cit. 29. 4. 2020]. Dostupné z: https://www.lawfareblog.com/danger-deepfakes-responding-bobby-chesney-and-daniellecitron

${ }^{141}$ CITRON, FRANKS, op. cit., s. 362.
} 
Je však namístě zdůraznit slovo prozatím. Stejně jako se zde objevují i jiné formy nekonsenzuální pornografie, je možno očekávat i rozšíření deepfake pornografie. S ohledem na popsanou závažnost újmy, kterou šíření takových nahrávek může zpo̊sobovat, je tedy třeba, aby na to právní řád byl schopen efektivně reagovat.

\section{LITERATURA}

\subsection{MONOGRAFIE}

[1] BARTOŇ, Michal a kol. Základní práva. 1. vydání. Praha: Leges, 2016, 608 s. ISBN 978-80-7502-128-1.

[2] HENRY, Nicola; FLYNN, Asher; POWELL, Anastasia. Responding to 'revenge pornography': Prevalence, nature and impacts [online]. 1. vydání. Canberra: Australian Research Council, 2019 [cit. 27. 4. 2020], 126 s. ISBN 978-1-925304-14-5. Dostupné z: https://www.crg.aic.gov.au/ reports/CRG_08_15-16-FinalReport.pdf

[3] POWELL, Anastasia; HENRY, Nicola. Sexual Violence in a Digital Age [online]. 1. vydání. Basingstoke: Palgrave Macmillan, 2017 [cit. 27. 4. 2020], 317 s. ISBN 978-1-137-58047-4. Dostupné z: https://link.springer.com/book/10.1057\%2F978-1-137-58047-4

\subsection{KAPITOLA Z MONOGRAFIE}

[4] WAGNEROVÁ, Eliška. Právo na soukromí v širším smyslu. In: WAGNEROVÁ, Eliška a kol. Listina základních práv a svobod: komentár̆. 1. vydání. Praha: Wolters Kluwer ČR, 2012, s. 277299. ISBN 978-80-7357-750-6.

\subsection{PŘÍSPĚVKY VE SBORNÍKU}

[5] ROUVROY, Antoinette; POULLET, Yves. The Right to Informational Self-Determination and the Value of Self-Development: Reassessing the Importance of Privacy for Democracy. In: GUTWIRTH, Serge et kol. (ed.). Reinventing Data Protection? [online]. 1. vydání. Dordrecht: Springer, 2009, s. 45-76. ISBN 978-1-4020-9498-9. Dostupné z: https://link.springer.com/ chapter/10.1007/978-1-4020-9498-9_2

[6] WAGNEROVÁ, Eliška. Právo na soukromí: Kde má být svoboda, tam musí být soukromí. In: ŠIMÍČEK, Vojtěch (ed.). Právo na soukromí. 1. vydání. Brno: Masarykova univerzita, 2011, s. 49-62. ISBN 978-80-210-5449-3. 


\subsection{KVALIFIKAČNÍ PRÁCE}

[7] DVOŘÁKOVÁ, Michaela. Právo na informační sebeurčení a nedovolené šǐřní sexuálních záznamů [online]. Brno, 2018 [cit. 29. 4. 2020]. Diplomová práce. Masarykova univerzita, Právnická fakulta. Vedoucí práce Kateřina ŠIMÁČKOVÁ, $117 \mathrm{~s}$. Dostupné z: https:// is.muni.cz/th/t361z/

\section{5 ČLÁNKY Z ODBORNÝCH PUBLIKACÍ}

[8] BATES, Samantha. Revenge Porn and Mental Health: A Qualitative Analysis of the Mental Health Effects of Revenge Porn on Female Survivors. Feminist Criminology [online]. 2017, roč. 12, 1 [cit. 27. 4. 2020] s. 22-42. ISSN: 1557-086X. Dostupné z: http:// journals.sagepub.com/doi/abs/10.1177/1557085116654565

[9] CITRON, Danielle Keats. Sexual Privacy. The Yale Law Journal [online]. 2018-2019, roč. 128, 7 [cit. 29. 4. 2020], s. 1870-1960. ISSN: 1939-8611. Dostupné z: https://www.yalelawjournal.org/article/sexual-privacy

[10] CITRON, Danielle Keats; FRANKS, Mary Anne. Criminalizing Revenge Porn. Wake Forest Law Review [online]. 2014, roč. 49, [cit. 27. 4. 2018], s. 345-391. ISSN: 0043-003X. Dostupné z: http://repository.law.miami.edu/cgi/viewcontent.cgi?

article $=1059 \&$ context $=$ fac $\_$articles

[11] DELFINO, Rebecca. Pornographic Deepfakes: The Case for Federal Criminalization of Revenge Porn's Next Tragic Act. Fordham Law Review [online]. 2019, roč. 88, 3 [cit. 27. 4. 2020], s. 887-938. ISSN: 0015-704X. Dostupné z: https://ir.lawnet.fordham.edu/ flr/vol88/iss3/2/

[12] FRANKS, Mary Anne; WALDMAN, Ari Ezra. Sex, Lies, and Videotape: Deep Fakes and Free Speech Delusions. Maryland Law Review [online]. 2019, roč. 78, 4 [cit. 29. 4. 2020], s. 892-898. ISSN: 0025-4282 Dostupné z: https://digitalcommons.law.umaryland.edu/cgi/ viewcontent.cgi?article $=3835 \&$ context $=\mathrm{mlr}$

[13] HALL, Holly Kathleen. Deepfake Videos: When Seeing Isn't Believing. Catholic University Journal of Law and Technology [online]. 2018, roč. 27, 1 [cit. 27. 9. 2020], s. 51-76. ISSN: 1068-5871. Dostupné z: https://scholarship.law.edu/cgi/viewcontent.cgi? article $=1060 \&$ context $=\mathrm{jlt}$

[14] HARRIS, Douglas. Deepfakes: False Pornography Is Here and the Law Cannot Protect You. Duke Law \& Technology Review [online]. 2019, roč. 17, 1 [cit. 28. 4. 2020], s. 99-127. ISSN: 2328-9600 Dostupné z: https://scholarship.law.duke.edu/dltr/vol17/iss1/4/

[15] CHESNEY, Robert; CITRON, Danielle Keats. Deep Fakes: A Looming Crisis for National Security, Democracy and Privacy? California Law Review [online]. 2019, roč. 107, 6 [cit. 29. 4. 2020], s. 1753-1820. ISSN: 1942-6542. Dostupné z: http://www.californialawreview.org/print/deep-fakes-a-looming-challenge-for-privacy-democracy-and-nationalsecurity/ 
[16] KIRCHENGAST, Tyrone; CROFTS, Thomas. The legal and policy contexts of 'revenge porn' criminalisation: the need for multiple approaches. Oxford University Commonwealth Law Journal [online]. 2019, roč. 19, 1 [cit. 28. 4. 2020], s. 1-29. ISSN: 1757-8469. Dostupné z: https://www.tandfonline.com/doi/abs/ 10.1080/14729342.2019.1580518? journalCode $=$ rouc20

[17] MCGLYNN, Clare; RACKLEY, Erika. Image-Based Sexual Abuse. Oxford Journal of Legal Studies [online]. 2017, roč. 37, 3 [cit. 6. 4. 2020], s. 534-561. ISSN: 1464-3820. Dostupné z: https://academic.oup.com/ojls/article-abstract/37/3/534/2965256? redirectedFrom = fulltext

[18] MESARČíK, Matúš; ZIMEN, Ondrej. Deep fakes a ochrana súkromia. Acta Facultatis Iuridicae Universitatis Comenianae [online]. 2019, roč. 38, 2 [cit. 29. 4. 2020] s. 227-242. ISSN: 1336-6912. Dostupné z: https://afi.flaw.uniba.sk/index.php/AFI/article/view/65

[19] NISSELBAUM, Helen. Protecting Privacy in an Information Age: The Problem of Privacy in Public. Law and Philosophy [online]. 1998, roč. 17, 5/6 [cit. 29. 4. 2020], s. 559-596. ISSN: 0167-5249. Dostupné z: https://www.jstor.org/stable/3505189? seq $=1$ \#metadata_info_tab_contents

[20] ÖHMAN, Carl. Introducing the pervert's dilemma: a contribution to the critique of Deepfake Pornography. Ethics and Information Technology [online]. 2019 [cit. 29. 4. 2020]. ISSN: 1572-8439. Dostupné z: https://link.springer.com/article/10.1007/s10676-019-09522-1

[21] REIMAN, Jeffrey H. Privacy, Intimacy and Personhood. Philosophy and Public Affairs [online]. 1976, roč. 6, 1 [cit. 26. 9. 2020], s. 26-44. ISSN: 1088-4963. Dostupné z: https:// www.jstor.org/stable/2265060?seq $=1$

[22] SPIVAK, Russell. "Deepfakes": The Newest Way to Commit One of the Oldest Crimes. Georgetown Law Technology Review [online]. 2019, roč. 3, 2 [cit. 27. 4. 2020], s. 339-400. Dostupné z: https://georgetownlawtechreview.org/wp-content/uploads/ 2019/05/3.1-Spivak-pp-339-400.pdf

[23] ŠEPEC, Miha. Revenge Dissemination of Sexually Explicit Material as a Sexual Offence or as a Privacy Violation Offence Pornography or Non-Consensual. International Journal of Cyber Criminology [online]. 2019, roč. 13, 2 [cit. 29. 4. 2020], s. 418-438. ISSN: 0974-2891. Dostupné z: https://www.cybercrimejournal.com/MihaSepecVol13Issue2IJCC2019.pdf

[24] VACCARI, Christian; CHADWICK, Andrew. Deepfakes and Disinformation: Exploring the Impact of Synthetic Political Video on Deception, Uncertainty, and Trust in News. Social Media + Society [online]. 2020, roč. 6, $1 \quad$ [cit. 27. 9. 2020], s. 1-12. ISSN: 2056-3051. Dostupné z: https://journals.sagepub.com/doi/pdf/ $10.1177 / 2056305120903408$ 


\subsection{ELEKTRONICKÉ ZDROJE}

[25] 2013 NCP Study Results. In: Cyber Civil Rights Initiative [online]. (C2018 [cit. 27. 4. 2020]. Dostupné z: https://www.cybercivilrights.org/wp-content/uploads/ 2016/11/NCP-2013-Study-Research-Results-1.pdf

[26] BERGER, Miriam. Brazilian 17-Year-Old Commits Suicide After Revenge Porn Posted Online. In: BuzzFeed News [online]. 20.11. 2013 [cit. 27. 4. 2020]. Dostupné z: https:// www.buzzfeed.com/miriamberger/brazilian-17-year-old-commits-suicide-after-revenge-pornpos?utm_term $=.1 x o O 1 z 9 r 4 \# . t x Z 2 n 7 a G r$

[27] BURÝŠKOVÁ, Lenka. Vydíral ženu přes facebook. In: Policie České republiky - Ǩ̌P Královéhradeckého kraje [online]. 2. 9.2016 [cit. 29. 4. 2020]. Dostupné z: http://www.policie.cz/clanek/vydiral-zenu-pres-facebook.aspx

[28] COLE, Samantha. Deepfakes Were Created As a Way to Own Women's Bodies-We Can't Forget That. In: Vice [online]. 19. 4. 2018 [cit. 30. 4. 2020]. Dostupné z: https://www.vice.com/en_us/article/j5kk9d/deepfakes-were-created-as-a-way-to-own-womens-bodieswe-cantforget-that-v25n2

[29] COLLINS, Ben. Russia-linked account pushed fake Hillary Clinton sex video. In: NBC News [online]. 11. 4. 2018 [cit. 29. 4. 2020]. Dostupné z: https://www.nbcnews.com/tech/ security/russia-linked-account-pushed-fake-hillary-clinton-sex-video-n864871

[30] DOLD, Kristen. Face-Swapping Porn: How a Creepy Internet Trend Could Threaten Democracy. In: Rolling Stone [online]. 17. 4. 2018 [cit. 29. 4. 2020]. Dostupné z: https:// www.rollingstone.com/culture/culture-features/face-swapping-porn-how-a-creepy-internettrend-could-threaten-democracy-629275/

[31] DRAHOKOUPILOVÁ, Lenka. Prozrazení hesla se jí nevyplatilo. In: Policie České republiky - Ǩ̌P Jihomoravského kraje [online]. 12.12. 2019 [cit. 29. 4. 2020]. Dostupné z: https:// www.policie.cz/clanek/prozrazeni-hesla-se-ji-nevyplatilo.aspx

[32] EATON, Asia A.; JACOBS, Holly; RUVALCABA, Yanet. 2017 Nationwide Online Study of Nonconsensual Porn Victimization and Perpetration. A Summary Report. In: Cyber Civil Rights Initiative [online]. (C2017 [cit. 27. 4. 2020], 28 s. Dostupné z: https://www.cybercivilrights.org/wp-content/uploads/2017/06/CCRI-2017-Research-Report.pdf

[33] ENGLAND, Charlotte. Teenager jailed for broadcast of girl's rape on online Periscope app. In: The Independent [online]. 15. 2. 2017 [cit. 28. 4. 2020]. Dostupné z: http://www.independent.co.uk/news/world/americas/teenager-marina-lonina-livestream-rape-17-year-oldfriend-periscope-app-sentence-prison-columbus-a7581196.html

[34] FRANKS, Mary Anne. Combating Non-Consensual Pornography: A Working Paper. In: SSRN [online]. 7. 9. 2014 [cit. 27. 4. 2020], 17 s. Dostupné z: https://papers.ssrn.com/sol3/ papers.cfm?abstract_id $=2336537$ 
[35] GESSEN, Masha. The Terrorization of Katie Hill. In: The New Yorker [online]. 5. 11. 2019 [cit. 27. 4. 2020]. Dostupné z: https://www.newyorker.com/news/our-columnists/the-terrorization-of-katie-hill?utm_campaign $=$ falcon\&utm_source $=$ facebook\&utm_social-type $=$ owned\&mbid $=$ social_facebook\&utm_medium $=$ social\&utm_brand $=$ tny\&fbclid = IwAR01EotER_b QTgbX5dqMmKMqlU84hNshdxAqDM08LV9pCxAAuA-ucHp506s

[36] GSTALTER, Morgan. 'Obama' Voiced by Jordan Peele in PSA Video Warning About Fake Videos. In: The Hill [online]. 17. 4. 2018 [cit. 29. 4. 2020]. Dostupné z: https://thehill.com/ blogs/in-the-know/in-the-know/383525-obama-voiced-by-jordan-peele-in-psa-video-warningabout-fake

[37] HLAVÁČOVÁ, Veronika; DUCHKOVÁ, Anna. Internetový sexuální predátor se mi naboural do webkamery a sledoval, jak se převlékám, říká Monika. In: iROZHLAS [online]. 2. 3. 2020 [cit. 29. 4. 2020]. Dostupné z: https://www.irozhlas.cz/zivotni-styl/spolecnost/internetovy-sexualni-predator-serial-pojd-si-se-mnou-psat-webkamera-v-siti_2003021909_jgr

[38] JANDA, Petr. Zneužití fotografie. In: Policie České republiky - KǨP Královéhradeckého kraje [online]. 7. 3. 2012 [cit. 29. 4. 2020]. Dostupné z: https://www.policie.cz/clanek/zneuzite-fotografie.aspx

[39] JIROUŠKOVÁ, Pavla. Láska přes internet nedopadla dobře. In: Policie České republiky Ǩ̌P Moravskoslezského kraje [online]. 26.11. 2019 [cit. 29. 4. 2020]. Dostupné z: https:// www.policie.cz/clanek/laska-pres-internet-nedopadla-dobre.aspx

[40] KOPECKÝ, Kamil; SZOTKOWSKI, René. Sexting a rizikové seznamování českých dětí v kyberprostoru. Výzkumná zpráva. In: Univerzita Palackého v Olomouci ve spolupráci se společností 02 Czech Republic [online]. (C2017 [cit. 29. 4. 2020]. Dostupné z: https://www.ebezpeci.cz/index.php/ke-stazeni/vyzkumne-zpravy/96-sexting-a-rizikove-seznamovani-2017/ file

[41] KOZUMPLÍKOVÁ, Monika. Než pošleš nahou fotku, přemýšlej!. In: Policie České republiky - KŘP Zlínského kraje [online]. 31. 10. 2019 [cit. 29. 4. 2020]. Dostupné z: https://www.policie.cz/clanek/nez-posles-nahou-fotku-premyslej.aspx

[42] KYŠNEROVÁ, Simona. Vydíral ji jejími nahými fotkami. In: Policie České republiky - KǨP Zlínského kraje [online]. 12.1. 2017 [cit. 29. 4. 2020]. Dostupné z: http://www.policie.cz/ clanek/vydiral-ji-jejimi-nahymi-fotkami.aspx

[43] LADMANOVÁ, Dana. Důvěřivé ženy. In: Policie České republiky - KŘP Plzeňského kraje [online]. 27. 12. 2017 [cit. 29. 4. 2020]. Dostupné z: http://www.policie.cz/clanek/duverivezeny.aspx

[44] LENHART, Amanda; YBARRA, Michelle; PRICE-FEENEY, Myeshia. Nonconsensual Image Sharing: one in 25 Americans has been a victim of "Revenge Porn". In: Data \& Society Research Institute [online]. 13. 12. 2016 [cit. 28. 4. 2020], 8 s. Dostupné z: https://datasociety.net/pubs/oh/Nonconsensual_Image_Sharing_2016.pdf

[45] LEWENDOWSKI, Amanda. Our Best Weapon Against Revenge Porn: Copyright Law?. In: The Atlantic [online]. 4. 2. 2014 [cit. 29. 4. 2020]. Dostupné z: https://www.theatlantic.com/ technology/archive/2014/02/our-best-weapon-against-revenge-porn-copyright-law/283564/ 
[46] LIN, Herb; HOLLAND, Hank J. The Danger of Deepfakes: Responding to Bobby Chesney and Danielle Citron. In: Lawfare [online]. 27. 2. 2018 [cit. 29. 4. 2020]. Dostupné z: https:// www.lawfareblog.com/danger-deepfakes-responding-bobby-chesney-and-danielle-citron

[47] MATZNER, Jiří. Vydírá expřítelkyni zveřejněním intimních fotografií. In: Policie České republiky - KŘP Jihočeského kraje [online]. 3. 5. 2015 [cit. 29. 4. 2020]. Dostupné z: http:// www.policie.cz/clanek/vydira-expritelkyni-zverejnenim-intimnich-fotografii.aspx

[48] MORAVČÍK, Ondřej. Když čtrnáctiletá Kristýna... In: Policie České republiky - KŘP Královéhradeckého kraje [online]. 20. 3. 2019 [cit. 29. 4. 2020]. Dostupné z: https://www.policie.cz/clanek/kdyz-ctrnactileta-kristyna.aspx

[49] RAFFAGHELLO, Ida a kol. What Does a Feminist Approach to Deepfake Pornography Look Like?. In: Masters of Media [online]. 24. 10. 2019 [cit. 28. 4. 2020]. Dostupné z: https://mastersofmedia.hum.uva.nl/blog/2019/10/24/what-does-a-feminist-approach-todeepfake-pornography-look-like/

[50] REYNOLDS, James. Italy's Tiziana: Tragedy of a woman destroyed by viral sex video. In: $B B C$ [online]. 13. 2. 2017 [cit. 27. 4. 2020]. Dostupné z: http://www.bbc.com/news/worldeurope-38848528

[51] ROSEN, Jeffrey. The Web Means the End of Forgetting. In: The New York Times Magazine [online]. 21. 7. 2010 [cit. 27. 4. 2020]. Dostupné z: https://www.nytimes.com/ 2010/07/25/magazine/25privacy-t2.html

[52] SANGHANI, Radhika. Chrissy Chambers: 'My rape became revenge porn in the UK'. In: The Telegraph [online]. 17. 6. 2015 [cit. 29. 4. 2020]. Dostupné z: https://www.telegraph.co.uk/women/womens-life/11677742/YouTube-Chrissy-Chambers-My-rape-became-revengeporn-in-the-UK.html

[53] SCHNEEWEISSOVÁ, Barbora. Sedmadvacetiletý muž několik let přes sociální sítě obtěžoval nezletilé dívky. In: Policie České republiky - Ǩ̌P Středočeského kraje [online]. 25. 11. 2019 [cit. 29. 4. 2020]. Dostupné z: https://www.policie.cz/clanek/sedmadvacetiletymuz-nekolik-let-pres-socialni-site-obtezoval-nezletile-divky.aspx

[54] SHEAD, Sam. Facebook to ban 'deepfakes'. In: $B B C$ [online]. 7.1.2020 [cit. 29. 4. 2020]. Dostupné z: https://www.bbc.com/news/technology-51018758

[55] SMITH-SPARK, Laura; VANDOORNE, Saskya. Reports: Teen Daniel Perry commits suicide over Skype blackmail scam. In: CNN [online]. 16. 8. 2013 [cit. 27. 4. 2020]. Dostupné z: https://edition.cnn.com/2013/08/16/world/europe/uk-cyber-blackmail-suicide/ index.html

[56] Steubenville Ohio School Footballers Guilty of Rape. In: BBC [online]. 17. 32013 [cit. 29. 4. 2020]. Dostupné z: https://www.bbc.com/news/world-us-canada-21823042

[57] Tomáš Řepka půjde do vězení, odvolací soud mu zvýšil trest. In: iROZHLAS [online]. 30. 4. 2019 [cit. 30. 4. 2020]. Dostupné z: https://www.irozhlas.cz/sport/fotbal/tomas-repkavezeni-odvolaci-soud-2-roky-sparta-praha-zpronevera_1904301028_vman 
[58] WINKLEY, Lyndsay; LITTLEFIELD, Dana. Sentence revised for revenge porn site operator. In: The San Diego Union-Tribune [online]. 21. 9. 2015 [cit. 27. 4. 2020]. Dostupné z: http://www.sandiegouniontribune.com/sdut-kevin-bollaert-revenge-porn-case-resentencing2015sep21-story.html

[59] ZÁMEČNÍK, Petr. Začalo to nevinně. In: Policie České republiky - Ǩ̌P Jihomoravského kraje [online]. 23. 3. 2018 [cit. 29. 4. 2020]. Dostupné z: https://www.policie.cz/clanek/ zacalo-to-nevinne.aspx

[60] ŽLÁBKOVÁ, Ludmila. Snímky polonahých dívek od zhrzených partnerů zaplavily český internet. In: Novinky.cz [online]. 9. 11.2014 [cit. 27. 4. 2020]. Dostupné z: https:// www.novinky.cz/internet-a-pc/352987-snimky-polonahych-divek-od-zhrzenych-partneruzaplavily-cesky-internet.html

\subsection{ROZHODNUTÍ ČESKÝCH SOUDŮ}

[61] Nález Ústavního soudu ze dne 11. 11. 2005, sp. zn. I. ÚS 453/03.

[62] Nález Ústavního soudu ze dne 20. 12. 2016, sp. zn. Pl. ÚS 3/14.

[63] Rozsudek Nejvyššího soudu ze dne 27. 5. 2015, sp. zn. 30 Cdo 5216/2014.

[64] Usnesení Nejvyššího soudu ze dne 14. 7. 2015, sp. zn. 4 Tdo 843/2015.

\subsection{ROZHODNUTÍ SOUDNÍHO DVORA EU}

[65] Rozsudek Soudního dvora (velkého senátu) ze dne 13. 5. 2014 ve věci C-131/12, Google Spain and Google, ECLI EU:C:2014:317.

\subsection{ROZHODNUTÍ EVROPSKÉHO SOUDU PRO LIDSKÁ PRÁVA}

[66] Rozsudek Evropského soudu pro lidská práva ze dne 22. 10. 1981. Dudgeon vs. Spojené království. ECHR 7525/76. In: HUDOC [online]. Evropský soud pro lidská práva [cit. 29. 4. 2020]. Dostupné z: http://hudoc.echr.coe.int/eng?i =001-57473

[67] Rozsudek Evropského soudu pro lidská práva ze dne 28. 1. 2003. Peck vs. Spojené království. ECHR 44647/98. In: HUDOC [online]. Evropský soud pro lidská práva [cit. 29. 4. 2020]. Dostupné z: http://hudoc.echr.coe.int/eng?i =001-60898

[68] Rozsudek Evropského soudu pro lidská práva ze dne 4. 12. 2008. S. a Marper vs. Spojené království. ECHR 30562/04 a 30566/04. In: HUDOC [online]. Evropský soud pro lidská práva [cit. 29. 4. 2020]. Dostupné z: http://hudoc.echr.coe.int/eng?i=001-90051

\subsection{ROZHODNUTÍ ZAHRANIČNÍHO SOUDU}

[69] Rozhodnutí Spolkového ústavního soudu SRN ze dne 15. 12. 1983, BVerfGE 65, 1. In: OpenJur [online]. 2012 [cit. 29. 4. 2020]. Dostupné z: https://openjur.de/u/268440.html 


\subsection{PRÁVNÍ PŘEDPISY ČR}

[70] Usnesení předsednictva České národní rady č. 2/1993 Sb., o vyhlášení Listiny základních práv a svobod jako součásti ústavního pořádku České republiky, ve znění ústavního č. zákona $162 / 1998 \mathrm{Sb}$.

[71] Zákon č. 480/2004 Sb., o některých službách informační společnosti.

[72] Zákon č. 40/2009 Sb., trestní zákoník.

[73] Zákon č. 89/2012 Sb., občanský zákoník.

\subsection{PRÁVNÍ PŘEDPISY EU}

[74] Nařízení Evropského parlamentu a Rady (EU) 2016/679 ze dne 27. 4. 2016 o ochraně fyzických osob v souvislosti se zpracováním osobních údajů a o volném pohybu těchto údajů a o zrušení směrnice 95/46/ES. In: EUR-lex [právní informační systém]. Úřad pro publikace Evropské unie. Dostupné z: https://eur-lex.europa.eu/legal-content/CS/TXT/PDF/?uri = CELEX:32016R0679\&from $=$ CS

[75] Směrnice Evropského parlamentu a Rady 2000/31/ES ze dne 8. 6. 2000 o některých právních aspektech služeb informační společnosti, zejména elektronického obchodu, na vnitřním trhu. In: EUR-lex [právní informační systém]. Úřad pro publikace Evropské unie. Dostupné z: https://eur-lex.europa.eu/legal-content/CS/TXT/PDF/? uri $=$ CELEX:32000L0031\&from $=\mathrm{EN}$

\subsection{MEZINÁRODNÍ SMLOUVY}

[76] Úmluva o ochraně lidských práv a základních svobod Rady Evropy ze dne 4. 11. 1950, ve znění Protokolů 11 a 14, s Protokoly 1, 4, 6, 7, 12 a 13. In: Evropský soud pro lidská práva [online]. Evropský soud pro lidská práva [cit. 30. 4. 2020]. Dostupné z: http://www.echr.coe.int/Documents/Convention_CES.pdf

Toto dílo lze užít v souladu s licenčními podmínkami Creative Commons BY-SA 4.0 International (http://creativecommons.org/licenses/by-sa/4.0/legalcode). 